\title{
Tectonic and climatic forcing on the Panj river system during the Quaternary
}

\author{
Margret C. Fuchs ${ }^{\mathrm{a}, *}$, Richard Gloaguen ${ }^{\mathrm{a}, \mathrm{b}}$, Eric Pohl ${ }^{\mathrm{a}}$ \\ ${ }^{a}$ Remote Sensing Group, Institute of Geology, TU Bergakademie Freiberg, Bernhard-von-Cotta-Strasse 2, 09599 Freiberg, Germany \\ ${ }^{b}$ Remote Sensing Group, Helmholtz Institute Freiberg for Resource Technology, Halsbrücker Strasse 34, 09599 Freiberg, Germany
}

\begin{abstract}
Surface processes involve complex feedback effects between tectonic and climatic influences in the high mountains of Pamir. The ongoing India-Asia collision provokes the development of east-west-trending mountain ranges that impose structural control on flow directions of the Pamir rivers. The evolving relief is further controlled by strong moisture gradients. The decreasing precipitations from the southern and western margins of the Pamir Plateau to its center, in their turn, control the emplacement of glaciers. Chronologies of glacial records from the Pamir Plateau attest for strong climatic variability during the Quaternary. Corresponding remnants of glacial advances suggest glacial morphodynamic restricted to $>4,000 \mathrm{~m}$ a.s.l. since marine isotope stage (MIS) 4. The Panj, the trunk river of Pamir, deflects from the predominant westward drainage, connecting its main tributaries at the western margin of the drainage basin. The geometry of the river network and the pattern of incision characterize the Panj as a composite river. River reaches of indicated low incision coincide with west-trending valleys, parallel to domes and their bounding faults. Valley shape ratios reflect increased incision in north-trending sections, but do not match with changes in the catchment geometry or erodibility of rock types. Modelled riverbed profiles distinguish three Panj reaches. The upstream increase in convexity suggests successive river captures in response to local base-level changes. The northward-deflected river reaches link the local base levels, which coincide with the southern boundaries of the Shakhdara and Yazgulom Dome and Darvaz Range. We argue that tectonics plays a large role controlling the drainage system of the Panj and hence surface processes in the Pamir mountains.
\end{abstract}

Keywords:

Pamir, Panj river network, Tectonic geomorphology, Glacial chronology, Fluvial incision, River profiles

\section{Introduction}

The Pamir mountains provide an outstanding natural laboratory to study the role of the forces that drive mountain shaping. The Pamir constitutes the westernmost part of the India-Asia collision zone, one of Earth's largest and most rapidly deforming intra-continental orogens (e.g. Le Pichon et al., 1992; Reigber et al., 2001; Mohadjer et al., 2010). Surface processes in such active orogens involve erosional and depositional mechanisms and their complex feedbacks, controlled by the interplay between tectonic and climatic forcing (e.g. Hack, 1957).

In the Pamir, the northward drift of the Indian plate (Reigber et al., 2001; Mohadjer et al., 2010) imposes relief along east-west-trending mountain ranges. The generated anisotropic relief guides the powerful Panj river system, which drains the Pamir. While most of the Pamir rivers align to the predominant east-west orientation of mountain ranges, the major trunk river, the Panj itself, deflects several times toward the north, thus cutting through the

\footnotetext{
*corresponding author

Email address: fuchsm@mailserver.tu-freiberg.de (Margret C. Fuchs)
}

major Cenozoic structures of the Pamir. The predominantly westward drainage and its major river deflections enable to determine changes in the role of factors controlling the organization of the river network. The fluvial incision along the Panj river course, especially across the main tectonic units of Pamir, constitutes a proxy of local river response. It records variations in forcing on local base levels in response to potential structural control from Late Cenozoic tectonics. The corresponding pattern of river incision in turn sets the pace for related surface processes such as hillslope response and hence relief evolution. The ability of the river system to incise and transport the material supplied to the river channels out of the orogen is also governed by the fluvial discharge (e.g. Leland et al., 1998; Burbank and Anderson, 2001; Brookfield, 2008) and therefore by climatic factors, especially precipitation (rain, snow). In the Pamir, the moisture supply is driven by the interaction of the midlatitude Westerlies, the Indian summer monsoon (ISM), and the Siberian High with the relief (e.g. Benn and Owen, 1998; Röhringer et al., 2012). Glacial features on the Pamir Plateau and in the westtrending valleys of the major Pamir rivers recorded considerable climatic variations during the Quaternary. Glacial landform dating, especially cosmogenic exposure dating 
of moraines at the Pamir Plateau, suggests the maximum Late Pleistocene glaciation during the marine isotope stage (MIS) 5 or earlier (Zech et al., 2005a; Abramowski et al., 2006; Röhringer et al., 2012). The timing and successively reduced extent of glacial advances indicate cycles asynchronous to those of the Northern Hemisphere. However, the Late Quaternary shifts in atmospheric circulations and their complex effects on the glacial history of the Pamir are yet not well understood (e.g. Röhringer et al., 2012).

In this paper, we evaluate the role of tectonic and climatic factors controlling the organization of the Panj river system during the Late Quaternary. Recording the effects of both tectonic and climatic forcing on local base level and fluvial discharge, the Panj river system constitutes an ideal proxy to understand the surface processes in Pamir. To characterize the structural control on the relief evolution, we first present the tectonic framework of the Pamir, with a focus on the timing and rates of neotectonic deformation and dome exhumation. We then describe the feedback effects between the evolving relief and the prevailing atmospheric circulations using remote sensing data. We include a review of the glacial chronologies to evaluate the extent and timing of glacial advances, which have affected the Pamir during the Late Quaternary. Based on the geomorphological characteristics of the Panj drainage system, we finally discuss the respective roles of tectonics and climate in controlling the surface response processes in Pamir.

\section{Tectonic background}

\subsection{Tectonic setting and structural units of Pamir}

The Pamir mountains form the northwestern continuation of the Tibetan Plateau at the northwestern end of the Indian-Asian collision zone (e.g. Schwab et al., 2004; Robinson et al., 2004). They are confined by the Hindu Kush to the south and the Tien Shan to the north, the Tajik Depression and the Tarim Basin limit the Pamir to the west and east, respectively (Fig. 1A, B). The first-order Pamir structure is characterized by Paleozoic to Mesozoic sutures, magmatic belts, and crustal blocks.

The tectonic units of Pamir are assumed to consist of along-strike equivalents of the Tibetan Plateau that accreted to the Eurasian plate (Burtman and Molnar, 1993; Schwab et al., 2004; Cowgill, 2010; Bershaw et al., 2012). Classically, the Pamir is divided into three distinct tectonic terranes: the Northern, Central, and Southern Pamir (Fig. 2; Burtman and Molnar (1993)). The Northern Pamir consists of a Paleozoic-Early Mesozoic suture, arc and accretionary wedge, similar to the Kunlun and the XilSongpan-Ganzi system of northern Tibet. The southward following Tanymas suture (TS in Fig. 2) is part of the Tibetan Jinsha suture. The Central Pamir comprises Paleozoic-Jurassic platform rocks with Middle-Late Triassic granitoid intrusions, which indicate a possible correlation to the Quiangtang block. The striking similarities to
Tibet are also expressed by the east-west-trending anticlinal structure of the Central Pamir. Granitoids attributed to the Rushan-Pshart suture (RPS in Fig. 2) are Jurassic (Schwab et al., 2004). The Southern Pamir consists of Proterozoic to Mesozoic gneisses and metasedimentary rocks with Cretaceous-Neogene granitoid intrusions, equivalent to the Lhasa block in Tibet (Vlasov et al., 1991; Schwab et al., 2004).

Structural domes expose crystalline basement rocks that are mantled by lower-grade to non-metamorphic cover rocks; these domes cover up to $30 \%$ of the surface exposure of the Pamir (Vlasov et al., 1991; Brunel et al., 1994; Robinson et al., 2004; Schwab et al., 2004; Schmidt et al., 2011; Stübner et al., 2012).

The Kurgovat dome exposes high-grade rocks metamorphosed in the Triassic (Schmidt et al., 2011). In contrast, the domes in the Central (Yazgulom, Sarez, Muskol and Shatput Domes) and Southern Pamir (ShakhdaraAlichur Dome) exhumed high-grade, middle to lower crustal metamorphic rocks of Cenozoic age (Fig. 2; Schmidt et al. (2011); Stübner et al. (2012)).

An Eocene-Oligocene burial and Miocene exhumation history applies for the Central Pamir Yazgulom, Sarez, Muskol and Shatput Domes (Fig. 2). Robinson et al. (2004) attribute their continuation in the eastern Pamir to the Muztagh Ata and Kongur Shan Domes. Cooling ages along the Kongur Shan fault imply exhumation rates of $4.2 \mathrm{~mm} / \mathrm{yr}$ for the last $7 \mathrm{Myr}$ (Robinson et al., 2010). The largest of the Pamir gneiss domes is the $350-90 \mathrm{~km}$ Shakhdara-Alichur composite gneiss dome in the Southern Pamir. Its structural geometry, kinematics and timing of exhumation involve >35-21 Myr crustal thickening, 21$2 \mathrm{Myr}$ north-south extensional doming, and footwall exhumation (Stübner et al., 2012). Cooling ages date the peak exhumation of the Shakhdara and Yazgulom Domes (cf. Fig. 2) to around $\sim 15 \mathrm{Myr}$ (Stübner et al., 2012). However, the detailed exhumation mechanisms and history of the Central and Southern Pamir domes still need to be refined.

\subsection{The crustal deformation in Pamir}

The dominant east-west orientation of mountain ranges (cf. Figs. 1, 2) is largely controlled by the crustal shortening due to the Cenozoic India-Asia convergence (Burtman and Molnar, 1993; Bershaw et al., 2012) and still ongoing northward propagation of the Indian plate (Reigber et al., 2001; Mohadjer et al., 2010) in line with local block rotation (Waldhoer et al., 2001). In contrast to models invoked for the neighboring Tibetan Plateau, crustal flow does not seem to be involved in the evolution of Pamir (Gloaguen and Ratschbacher, 2011). The India-Asia convergence resulted in thrust and strike-slip faulting, which follows the trend described by the Pamir salient (Bershaw et al., 2012). The active frontal ranges bend nearly $180^{\circ}$ from northern Afghanistan to western China. The Pamir includes two intermediate-depth intracontinental subduction zones resolvable by seismicity and 


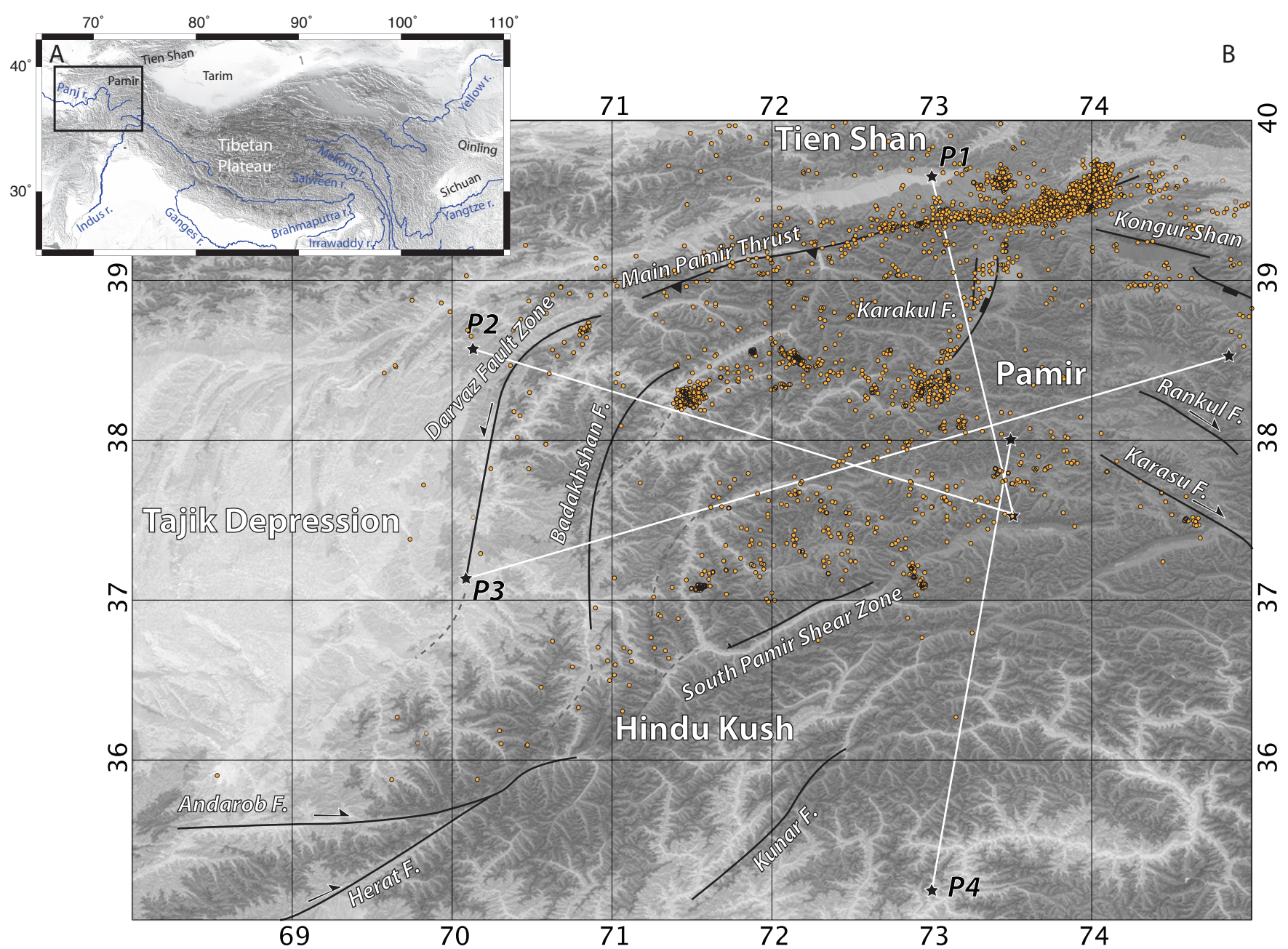

Figure 1: Tectonic setting of the Pamir within the intra-continental collision zone between India and Asia. A Location at the western end of the Himalaya-Tibetan orogen, B Distribution of seismic activity (Sippl et al., 2012) and location of the Swath profiles P1-4 (gray lines).

tomography (southern Pamir and Hindu Kush slabs; e.g., Koulakov and Sobolev (2006)).

The active deformation at the frontal part of the orocline is characterized by the south-dipping Main Pamir Thrust (MPT). The MPT is interpreted to be the surface expression of the seismically active southward subduction (cf. Fig. 1B), which has accommodated $\sim 300 \mathrm{~km}$ of shortening during the Cenozoic (Burtman and Molnar, 1993; Fan et al., 1994). The thrusting along the MPT is indicated to begin during the Late Oligocene and accommodates today $50 \%$ of the India-Asia convergence (Coutand et al., 2002; Bershaw et al., 2012). Shortening rates derived from GPS measurements reach about $20 \mathrm{~mm} / \mathrm{yr}$ or more across the MPT (Reigber et al., 2001; Mohadjer et al., 2010). Additional shortening of $\sim 300 \mathrm{~km}$ may have occurred along Pamir internal thrusts (Burtman and Molnar, 1993; Waldhoer et al., 2001). The timing of this shortening might include pre-Cenozoic periods (Robinson et al., 2007).

The lateral margins of the northward overthrusting along the MPT represent strike-slip faults that suggest transpression at the Darvaz Fault Zone (DFZ) in the west and transtension at the Karakoram Fault Zone (KFZ) in the east (e.g Fan et al., 1994; Robinson et al., 2007). The Late Quaternary lateral motion is $\sim 12 \mathrm{~mm} /$ yr across the DFZ (Trifonov, 1978). The active strike-slip motion along faults parallel to the KFZ in southeastern Pamir suggests $<1 \mathrm{~mm} / \mathrm{yr}$

(e.g. Strecker et al., 1995). Cowgill (2010) determined an average dextral strike-slip rate of $11-15 \mathrm{~mm} / \mathrm{yr}$ at the eastern margin of Pamir over the Late Cenozoic. Chevalier et al. (2012) suggest constant along-strike-slip rates of $>5$ $11 \mathrm{~mm} / \mathrm{yr}$ at the KFZ for the last $200 \mathrm{kyr}$, while Sobel et al. (2011) suggest slow dextral strike-slip rates of 1.7$5.2 \mathrm{~mm} / \mathrm{yr}$ or less between the Eastern Pamir and the Tarim Basin over the past 5-3 Myr. To the south, the boundary of the Pamir is complex and our field observations indicate a major east-west, low-angle normal fault bounding the Shakhdara Dome to the south, referred to as Southern Pamir Shear Zone (SPSZ, cf. Figs. 1, 2). 


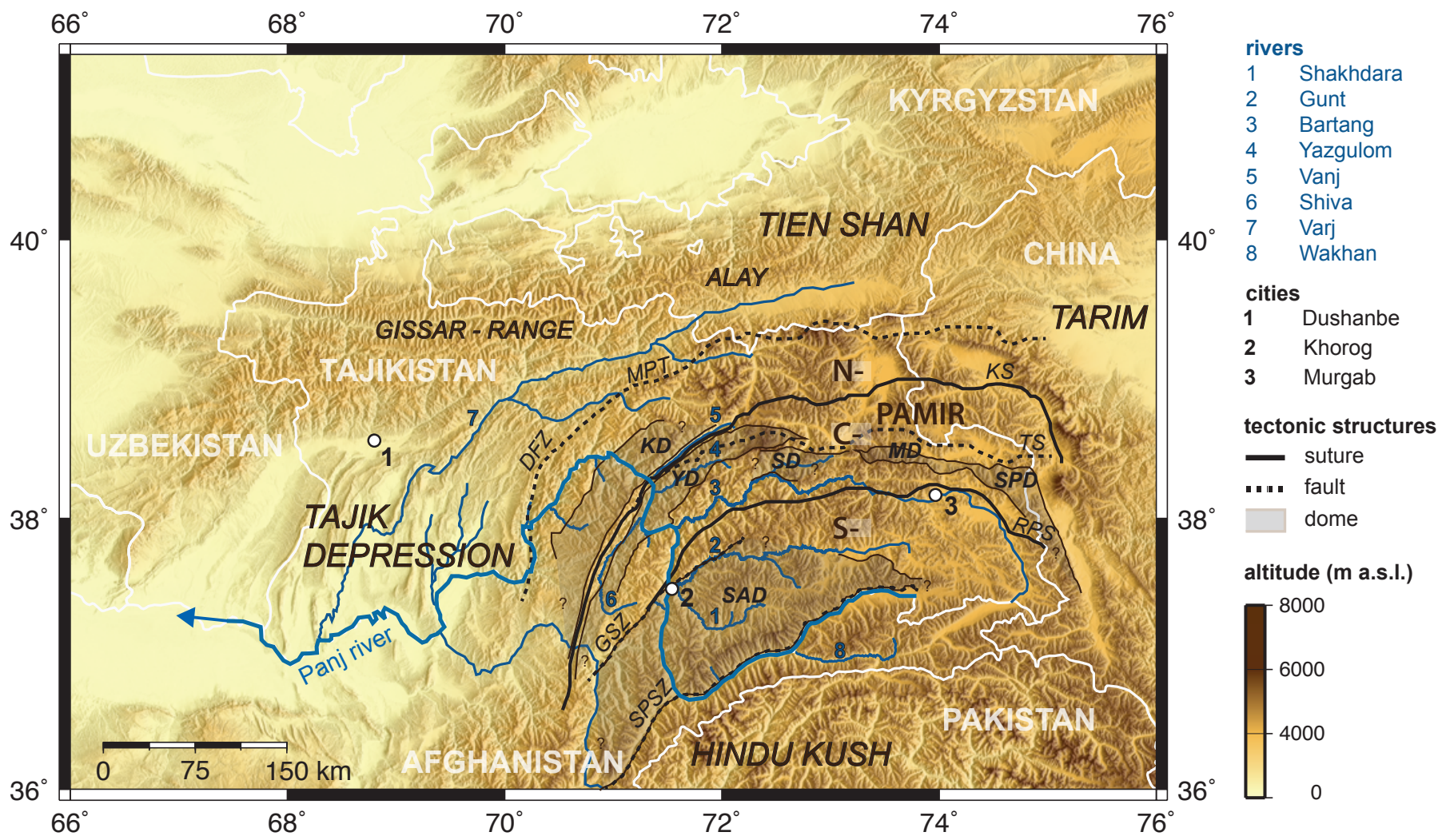

Figure 2: Main tectonic structures that characterize the Northern, Central, and Southern Pamir (N Northern, C Central, S Southern, DFZ Darvaz Fault Zone, MPT Main Pamir Thrust, KS Kunlun Suture, TS Tanymas suture, RPS Rushan-Psart-Suture, GSZ Gunt Shear Zone, SPSZ Southern Pamir Shear Zone, KD Kurgovat Dome, YD Yazgulom Dome, SAD Shakhdara-Alichur Dome, SD Sarez Dome, MD Muskol Dome, SPD Shatput Dome), and the Panj drainage network.

The elevated Pamir Plateau (Ducea et al. (2003), cf. Figs. 1, 2, 3) is crosscut by N-S striking normal faults, extending from the Karakul Lake to the Wakhan of Afghanistan (cf. Fig. 1B). Kinematic models of the active extension in the Pamir discuss topographic collapse (Brunel et al., 1994), radial overthrusting (Strecker et al., 1995), and links to the right-slip KFZ (Ratschbacher et al., 1994). Along the eastern boundary of the Pamir, the crustal extension is accommodated along the Kongur Shan extensional system (e.g. Fan et al., 1994; Robinson et al., 2007). Robinson et al. (2007) link the overall pattern of decreasing magnitude of east-west extension from $\sim 35-30 \mathrm{~km}$ in the north (Kongur Shan) to $\sim 20 \mathrm{~km}$ (Muztagh Ata) and $<3 \mathrm{~km}$ (along the Tashkorgan fault) in the south to the radial overthrusting of the Pamir salient along the MPT. The east-west extension at the Kongur Shan normal fault likely prevailed since 7-8 Myr (Robinson et al., 2004, 2010). Apart from those extensional structures, active internal deformation is limited. A series of north-west-striking right-slip faults in the southeastern Pamir determined slip rates of $<1 \mathrm{~mm} / \mathrm{yr}$ (Strecker et al., 1995; Robinson et al., 2007).

Active seismicity (Fig. 1B; Sippl et al. (2012)) and our own structural studies indicate that tectonic activity is now concentrated along the orogen margins and along the Karakul rift zone, whereas other internal structures, such as the dome margins, seem to be less active. The seismic network geometry does not allow for resolving earthquakes in Afghanistan, and therefore, it is still unclear whether some structures are currently seismogenic in Badakhshan (Schurr et al., 2011; Sippl et al., 2012). Faults associated with the DFZ such as the Central Badakhshan fault have prominent morphological characteristics and seem to merge with peripheral dome structures. Nonetheless, seismic activity, albeit weak, attests the existence of active deformation along the Gunt and the Vanj valleys along the northern boundaries of the Shakhdara and Yazgulom Dome (Fig. 2).

\section{Climate}

\subsection{Climatic setting}

The climate of the Pamirs is characterized by the transition between two atmospheric circulation systems (Fig. 3A). Most precipitation is provided by the Westerlies in the winter and spring seasons and by the ISM in the summer and autumn seasons. The interplay with the 

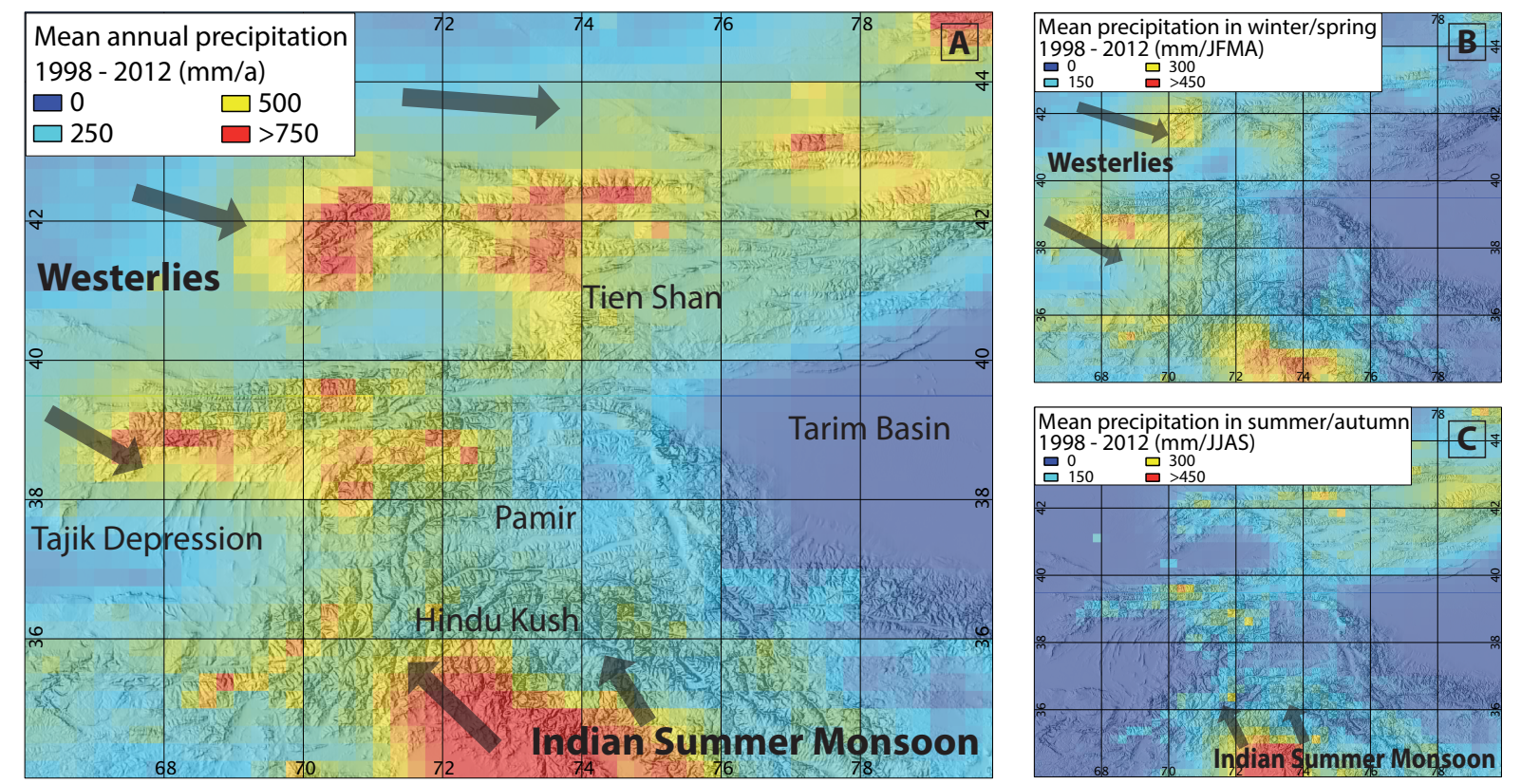

Figure 3: The pattern of moisture supply (TRMM product 3B42 V7) to Pamir controlled by the prevalent atmospheric circulations of the Westerlies and the Indian Summer Monsoon and their interplay with relief. A Distribution of the mean (1998-2012) annual precipitation, including the assumed influence from predominant atmospheric circulations of the Westerlies and the Indian Summer Monsoon. B Mean (1998-2012) winter to spring precipitation (given as a sum of January, February, March, and April). C Mean (1998-2012) summer precipitation (given as a sum of June, July, August, and September)

orographic rise directs the Westerlies north- and southwards of the Pamir and causes concentrated precipitation at the margins of the orogen. Towards the eastern plateau, precipitation decreases (cf. Fig. 3B, compare to Fig. 5, profile P3). Precipitation from the ISM decreases from the southeast toward the central Pamir and toward the Tibetan Plateau (Fig. 3C). High mountain ranges, such as the Karakoram and Hindu Kush, effectively shield the Pamir from the ISM (Fig. 3, compare to Fig. 5, profile P4).

In order to outline the seasonal and the orographic effects on the local climate, we use precipitation distribution and permanent ice or snow cover as proxies (cf. Figs. 3, 4, 5). We use the precipitation data from the Tropical Rainfall Measuring Mission (TRMM) product 3B42 V7 (Huffman et al., 1997, 2007). This data set combines infrared (IR) and microwave information from TRMM instruments to adjust merged IR precipitation data of several weather satellites and includes rain gauge measurements where feasible. The pattern of average annual, average winter/spring (Jan-Feb-Mar-Apr), and average summer/autumn (Jun-Jul-Aug-Sep) accumulated precipitation is derived from the TRMM data product in $0.25^{\circ} \times 0.25$ spatial resolution. TRMM3B42 data have been reported to be in agreement with in situ data for example in the Himalayas (e.g. Roe, 2005; Bookhagen and Burbank, 2010; Andermann et al., 2011). The detection of snowfall can be subject to high bias and is in the focus of current data improvement (Prigent, 2010). Even though TRMM is designed for detecting rainfall, it has been shown that mi- crowave imagers are capable of detecting snowfall (Skofronick-Jackson et al., 2004). Besides, TRMM3B42 is a data set resulting from the joint post-processing of remote sensing data and gauge stations (Huffman et al., 1997, 2007). Additionally, our own validation with in situ gauges confirms that TRMM3B42 data are adequate to assess bulk precipitation in the Pamir (Pohl and Gloaguen, 2012). The fact that there are data records of TRMM3B42 in winter gives further evidence of snowfall detection. This is of special interest for the western Pamir, which receives most of the precipitation as snow in winter and spring.

The time span of TRMM acquisition (launched in 1997) does not represent a climatic record of at least 30 years, but in contrast to weather re-analysis data, e.g., the ECMWF ERA Interim (Dee et al., 2011), TRMM3B42 has a superior spatial resolution and thus improves the recognition of regional features. We assume that the 14-year time span is representative of the climatic conditions in the Pamir. The TRMM-derived precipitation data suggest up to threefold, Westerlies-induced precipitation gradient from western to eastern Pamir (Figs. 3B, 5, swath profiles P2 and P3) and up to fivefold, ISM-induced gradient from southeastern Hindu Kush $(\sim 1,600 \mathrm{~mm} / \mathrm{yr})$ toward the eastern Pamir $(<300 \mathrm{~mm} / \mathrm{yr}$ ) (Figs. 3C, 5, swath profile P4). Overall, the west-east and south-north gradients in precipitation reflect a semiarid western and an arid central-eastern Pamir (cf. Zech et al. (2005a); Abramowski et al. (2006); Barry (2008)).

The distribution of permanent ice and snow cover is af- 

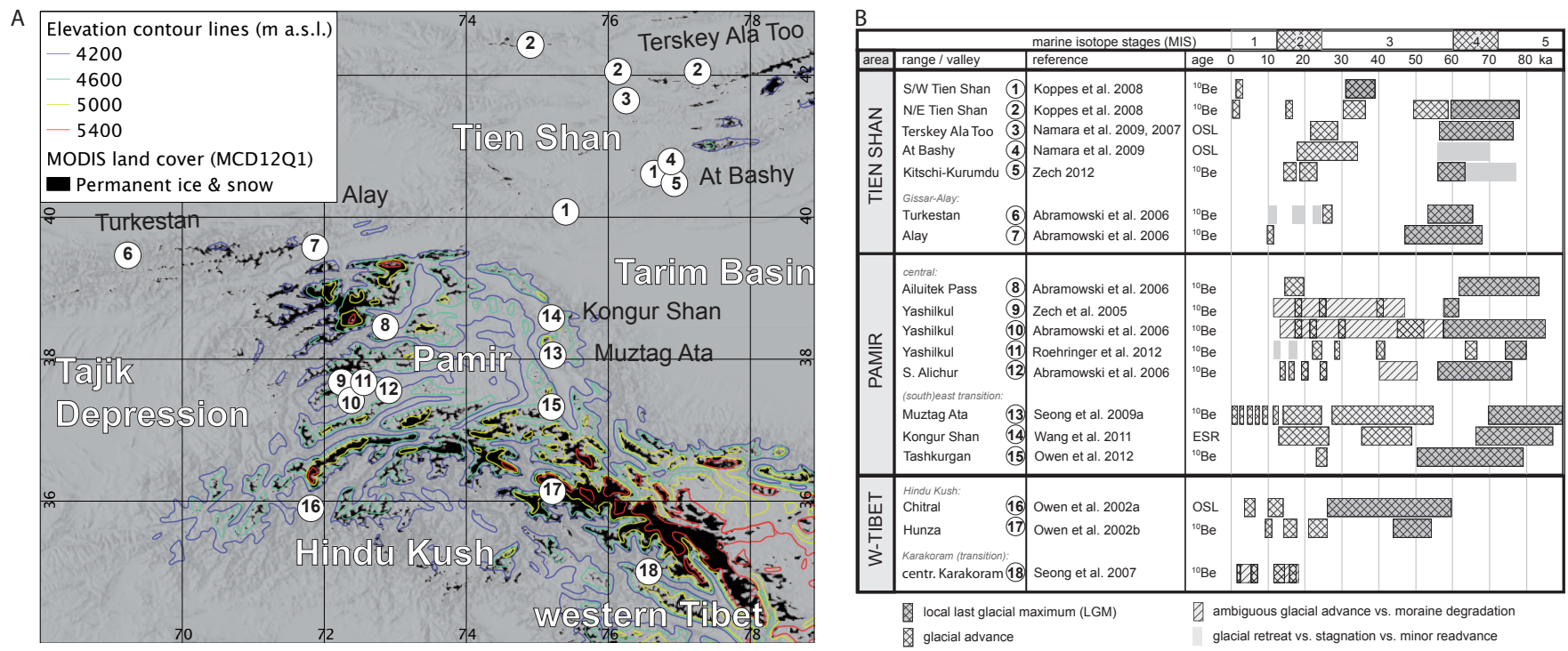

Figure 4: The timing and extent of glacial advances in Pamir. Tien Shan and Karakoram since the last glacial cycle. A Location of study sites concerning Quaternary glacial advances in relation to the distribution of permanent snow and ice cover (black, based on MCD12Q1). The comparison to altitude contour lines illustrates the superimposition of moisture gradients on the extent of glaciers (altitudes given in m a.s.l.). textbfB Overview about the glacial chronology for Pamir, Tien Shan, and Hindu Kush inferred from numerical dating of glacial deposits

fected by the temperature gradient at rising altitudes and by the moisture supply. Consequently, the low precipitation at the eastern Pamir Plateau restricts permanent ice and snow cover to much higher altitudes compared to that in western Pamir (cf. Fig. 4A, B). The extent of individual glaciers is sensitive to the regional and local air temperature and precipitation (Carrasco et al., 2005). It hence enables to discriminate between different regional climatic settings, refine conclusions drawn on precipitation distribution alone, and to reconstruct paleoclimatic conditions based on glacial remnants.

The steady-state condition of a glacier in equilibrium with the climate (net balance $=0$ ) results in glacier areas of accumulation and ablation. The line dividing these areas is the equilibrium line altitude (ELA) (Nesje, 1992). There are many different approaches for the calculation of the ELA, e.g., median elevation of glaciers (MEG), toe-to-headwall altitude ratio (THAR), ratio of the accumulation area to total area (AAR), or temperature- and precipitation-related approaches (for an overview, see Nesje (1992); Carrasco et al. (2005)). Nesje (1992) points out that glacier morphology and relief have substantial influences on the ELA calculation, in particular if the ablation area is at a different slope than the accumulation area. We use the ratio of the accumulation area to the total area (AAR). It allows us to pinpoint regional differences of modern glaciers extents and, additionally, to provide a basis for comparison with paleo-ELA estimated from glacial remnants. Several studies proposed a ratio of $0.6 \pm 0.05$ for steady-state conditions for cirque/valley glaciers (Nesje, 1992). The advantage of the AAR method lies in its ap- plicability to remote sensing data because glaciated area and elevation data are easily accessible. We use MODIS (Moderate Resolution Imaging Spectrometer) Land Cover Type data MCD12Q1 version 051 (Strahler et al., 1999) to extract the glaciated areas according to the annual predominant land cover type classification of the IGPB (International Geosphere Biosphere Programme). We superimpose the corresponding class for snow and ice on elevation data to a SRTM (Shuttle Radar Topography Mission) digital elevation model (DEM) (Jarvis et al., 2008). Using the AAR of $0.6 \pm 0.05$ ( $60 \%$ of glacier area above and $40 \%$ below the ELA), we extracted the elevation information for the 40th percentile. As we cannot assess steady-state conditions, we also accounted for negative and positive mass balances with ratios of 0.5 and 0.8 (50 and 20th percentile), respectively (Nesje, 1992). The average ELA for the Tien Shan, western and eastern Pamir, Hindu Kush, and the Karakoram Range is given in Table 1. The contour lines in Fig. 4 highlight the differences between the ELA of different regions, even closely located. In general, ELA for regions at the outer margins of the orogen shows lower values than those for the eastern Pamir and the Karakoram Range. Permanent ice and snow extent are strongly correlated with precipitation distribution (Figs. 3A, 4), suggesting precipitation as the limiting factor for glacier extent in Pamir.

\subsection{Quaternary glacial chronology}

\subsubsection{Geochronological framework}

Stratigraphic correlations of moraine generation provided a first framework for the glacial chronology in Cen- 
Table 1: ELA approximation for the eastern and western Pamir and adjacent regions.

\begin{tabular}{lrrr}
\hline Region & $\begin{array}{r}\text { 50th } \\
\text { [m a.s.l.] }\end{array}$ & $\begin{array}{r}\text { 40th } \\
{[\mathrm{m} \text { a.s.l.] }}\end{array}$ & $\begin{array}{r}\text { 20th } \\
\text { [m a.s.l.] }\end{array}$ \\
\hline Tien Shan [70-80E, 40-45N & & & \\
Hindu Kush [70-74E, 34-36N] & 4,277 & 4,206 & 4,040 \\
Western Pamir [66-73E, 37-40N] & 4,664 & 4,579 & 4,379 \\
Eastern Pamir [73-78E, 37-40N] & 5,100 & 4,750 & 4,473 \\
Kharakoram Range [74-80E, 34-37N] & 5,323 & 5,037 & 4,881 \\
& & & 4,841
\end{tabular}

The 50th, 40th and 20th percentile of extracted elevation data superimposed by MCD12Q1 permanent snow and ice cover. Percentiles represent negative, steady-state, and positive mass balances according to AARs of $0.5,0.6$ and 0.8 , respectively.

tral Asia (summary in Table 2; Zabirov (1955); Dodonov (2002)). But a robust reconstruction of the paleoclimate in Pamir, which allows the interpretation of links to shifts in the atmospheric circulation patterns and the comparison with adjacent regions or even global trends, relies on numerical dating. Especially, 10Be surface dating of moraine boulders has proven to yield quantitative measures for deciphering the regional context of those glacial records (cf. Fig. 4). We present here the glacial chronology in Pamir based on the available published records. However, the glacial remnants in Pamir indicate a high spatial variability and constraints about the glacial chronology rely on few study sites on the Pamir Plateau (Zech et al., 2005a; Abramowski et al., 2006; Röhringer et al., 2012), where today the climate is relatively dry (cf. Figs. 3, 4). Unfortunately, age constraints of glacial remnants from westtrending valleys at the Pamir margins are not available yet. Hence, possible paleogradients of glacial extends toward the west are not resolved. We include the adjacent areas of the Tien Shan to the north and the western Tibet to the south, to shed further light onto the varying prevalence of the Westerlies on the ISM. It allows us to evaluate the influence of shifting atmospheric circulations and the corresponding timing and extent of glacial process regimes during the Late Quaternary.

\subsubsection{Oldest glacial advances (Early MIS 4 and older)}

According to the oldest dated glaciation in the Pamir, an early local glacial maximum during MIS 4 or older has been proposed (Zech et al., 2005a; Abramowski et al., 2006; Röhringer et al., 2012). This early, most extensive glaciation is stratigraphically associated with the Early Pleistocene East-Pamir complex (cf. Table 2; Dodonov (2002)) or might represent remnants of a much-debated Late Pleistocene ice sheet covering the entire eastern Pamir (e.g. Kuhle, 1997, 2011). Exposure dating of the oldest moraines from Lake Yashilkul (Fig. 4, no. 9-11), from the Southern Alichur Range (Fig. 4, no. 12), and from the Ailuitek Pass (Fig. 4, no. 8) determines two age clusters at 93$136 \mathrm{kyr}$ (MIS 5) and 60-86 kyr (MIS 4/Late MIS 5) for the
Table 2: Stratigraphic correlation of glacial advances in Pamir (Zabirov, 1955; Dodonov, 2002).

\begin{tabular}{llrr}
\hline Moraine generation & Description & $\begin{array}{r}\text { Thickness } \\
{[\mathrm{m}]}\end{array}$ \\
\hline $\begin{array}{l}\text { Q1 (Early } \\
\text { Pleistocene, }\end{array}$ & West & $\begin{array}{r}\text { Tupchak/ } \\
\text { Kokbai }\end{array}$ & $\sim 1,000$ \\
$1-1.5 \mathrm{Ma})$ & East & $\begin{array}{r}\text { complex } \\
\text { East-Pamir } \\
\text { complex }\end{array}$ & $\sim 500-800$ \\
Q2 (Middle & West & $\begin{array}{r}\text { Bartang } \\
\text { complex }\end{array}$ & $\sim 300-400$ \\
Pleistocene, & East & $\begin{array}{r}\text { Murgab } \\
\text { complex }\end{array}$ & $\sim 200-300$ \\
$120-300$ ka) & West & $\begin{array}{r}\text { Badakhshan } \\
\text { complex } \\
\text { Alichur }\end{array}$ & $<200$ \\
Q3 (Late & East & complex & \\
Pleistocene, & Complex of all & & \\
Q4 (Holocene) & younger moraines &
\end{tabular}

Pamir Plateau (Zech et al., 2005a; Abramowski et al., 2006; Röhringer et al., 2012). The dated latero-frontal moraine that represents the most extensive moraine generation at Yashilkul is assumed to have crossed the Yashilkul valley reaching the opposite valley slope (Zech et al., 2005a; Röhringer et al., 2012). Although the continuation of this latero-frontal moraine is hidden below the water surface of the present-day Yashilkul, sediments on the northern shoreline might reflect this glacial advance to have reached the floors of inner-plateau valleys in Pamir. The finergrained moraine matrix corresponding to the dated boulders at the Southern Alichur Range is assumed as washed away (Abramowski et al., 2006). Two comparable age clusters can also be recognized in the eastern Pamir. Boulder exposure ages and electron spin resonance (ESR) ages associate the oldest, most extensive moraines in the Tashkurgan valley (Fig. 4, no. 15; Owen et al. (2012)) and in the Muztagh Ata and Kongur Shan (Fig. 4, no. 13 and 14; Seong et al. (2009a); Wang et al. (2011)) to MIS 5/MIS 6 and MIS 4/MIS 5.

Exposure ages from the oldest moraine generation further north in the Tien Shan agree to the indicated timing of glacial advances in the Pamir. The remnants of the most extensive glaciations correspond to advances during MIS 6 at At-Bashy (Fig. 4, no. 4; Zech (2012)), to Early MIS 5 and again during MIS 5-4 in the north and east Tien Shan (Koppes et al., 2008), and to pre-MIS 4 in the Turkestan Range (Fig. 4, no.6; Abramowski et al. (2006)).

However, the timing of the oldest glacial advances on the Pamir Plateau does not indicate a clear link to those south of Pamir. In the Chitral valley (Fig. 4, no. 16; Owen et al. (2002b)), Hindu Kush, no comparable glacial sediments were found and dated. Owen et al. (2002a) recognized two Late Pleistocene glaciations in the Hunza valley (Fig. 4, no. 17), but could only narrow the age to $>60 \mathrm{kyr}$. Two much older glacial advances before $700 \mathrm{kyr}$ and during MIS 6 or earlier were distinguished in the central Karako- 
ram (Fig. 4, no. 18; Seong et al. (2007)).

\subsubsection{The last glacial cycle (MIS 4 and 2)}

Prominent deposits of the last glacial cycle on the Pamir Plateau were dated to MIS 4 and MIS 2, and potentially to MIS 3, and suggest the local LGM during MIS 4 rather than during the global LGM during MIS 2 (Fig. 4A, B; Zech et al. (2005a); Abramowski et al. (2006)). Successively less extensive glacial advances over the course of the Late Pleistocene reflect the sensitivity to the increasing aridity in High Central Asia (Zech et al., 2005a; Abramowski et al., 2006; Herzschuh, 2006; Koppes et al., 2008; Narama et al., 2009). This trend is also recorded in maxima of loess accumulation between 25 and $20 \mathrm{kyr}$ in southern Tajikistan (Frechen and Dodonov, 1998). Causes of this increasing aridity are associated with the growing strength of the Siberian Anticyclone and a southward shift of the westerly jet stream (cf. Velichko et al. (1997); Hubberten et al. (2004); Zech et al. (2005a); Abramowski et al. (2006)). During the global LGM, both coincide with the collapse of the ISM (Phillips et al., 2000; Kamp et al., 2004; Zech et al., 2005a; Abramowski et al., 2006).

In Pamir, the second major advance is characterized by sets of latero-frontal moraines that accompany hummocky moraines. Such hummocky moraines are described from various locations throughout the Pamir and are associated with the Middle Pleistocene Bartang/Murgab complex (Dodonov, 2002), but numerical age constraints are challenging. At Lake Yashilkul, the two lateral moraines represent a Late MIS 4/Early MIS 3 and a MIS 3 stages. The outer one reveals exposure ages from 77 to $57 \mathrm{kyr}$, while the inner lateral moraine dates to $\sim 40 \mathrm{kyr}$ (Fig. 4, no. 9-11; Zech et al. (2005a); Abramowski et al. (2006); Röhringer et al. (2012)). The lateral moraines are difficult to correlate between study sites and do not allow for an identification of separate (re-)advances, also because their terminal parts are (glacio-)fluvially eroded (Röhringer et al., 2012). However, the indicated MIS 4 for the outer lateral moraine (Fig. 4, no.10) agrees to exposure ages between 57 and $75 \mathrm{kyr}$ of a latero-frontal moraine dated at the Southern Alichur Range (Fig. 4, no. 12; Abramowski et al. (2006)).

Exposure ages from the hummocky moraine itself, which reach the lake shoreline at lake Yashilkul, scatter between 65 and $12 \mathrm{kyr}$ (Fig. 4, no. 9; Zech et al. (2005a)). Zech et al. $(2005 \mathrm{a}, \mathrm{b})$ related the moraine generation to a cold period in western High Asia between $45 \mathrm{kyr}$ and $52 \mathrm{kyr}$ (Thompson et al., 1997) and hence argue the oldest ages to most likely represent the glacial advance during MIS 3. They refer the high scatter of younger ages to long-lasting ice decay and corresponding surface instability. However, they distinguish two subsequent glacial advances from the scattered ages, one at 30-27 kyr (MIS 3) and the other one at 24-22 kyr (MIS 2). A corresponding age cluster between 28 and $20 \mathrm{kyr}$ from the southern Alichur Range (Fig. 4, no. 12) is associated with the Alichur complex (Dodonov, 2002). The timing may be linked to a phase of intensified monsoon between 29 and 24 kyr (Bookhagen et al., 2005; Herzschuh, 2006). The timing of MIS 2 glacial advances at $\sim 24-22$ kyr and 20-18 kyr suggests slightly earlier or synchronous occurrence to the global LGM ( $\sim 20 \mathrm{kyr})$. Several age clusters indicate phases of accelerated moraine degradation or several recessional glacial stages at 16-15 and $\sim 12$ kyr (Fig. 4, no. 9-11; Zech et al. (2005a); Abramowski et al. (2006); Röhringer et al. (2012)). The glacial cycles in the Kongur Shan and Muztagh Ata, eastern Pamir, reflect basically the same pattern. The most prominent advance occurred during 87-66 kyr (MIS 4, local LGM) and the deposition of the hummocky moraines during 49-36 kyr (MIS 3). Younger exposure ages scatter between 27 and 13 kyr (MIS 2; Seong et al. (2009a); Wang et al. (2011)). Possible re-advances or recessional stages are indicated at $\sim 16 \mathrm{kyr}$ and 13-12 kyr (Seong et al., 2009a). No evidence for glacial advances at MIS 3, but for MIS 4 and MIS 2 is found to the south in the Tashkurgan valley (Owen et al., 2012).

To the north in the Tien Shan, surface exposure dating from the Alay-Turkestan Range (Abramowski et al. (2006); Fig. 4; no. 6 and 7), the At-Bashy (Zech (2012); Fig. 4; no.4), and OSL dating from the Teskey Ala-Too and At-Bashy Ranges (Narama et al. (2009); Fig. 4; no. 3 and 4), correspond to a local LGM in Tien Shan during the Late MIS 4 or Early MIS 3. Koppes et al. (2008) distinguish a shift toward MIS 3 in the south and east Tien Shan (Fig. 4; no. 1 and 2). The less prominent glaciation and subsequent degradation during MIS 2 are linked to clusters of exposure ages around 22, 20-16, and 12-10 kyr (e.g. Zech et al., 2005a; Abramowski et al., 2006; Narama et al., 2007).

South of Pamir, Owen et al. (2002b,a) found no evidence of a MIS 4 glaciation in the Hindu Kush and Karakoram mountains (Fig. 4, no. 16-18). The most extensive glaciation during 55-43 kyr, probably lasting until $27 \mathrm{kyr}$, represents the monsoon characteristic, local LGM during MIS 3 (Benn and Owen, 1998; Owen et al., 2002b,a). Several less prominent advances during 26-15 kyr (MIS 2) and earlier (Owen et al., 2002b,a; Seong et al., 2007) agree to the general trend of restricted MIS 2 glaciation in many areas of the Himalaya (Phillips et al., 2000; Richards et al., 2000a,b). In contrast, Kuhle (2011) infers an extensive ice sheet covering the Tibetan Plateau during the global LGM. Regional correlations and, in particular, the possibility of a Late Pleistocene plateau glaciation are still debated (for review, see, e.g., Derbyshire et al. (1991); Grosswald et al. (1994); Kuhle (2011)).

\subsubsection{The Holocene (post-MIS 2)}

The Early Holocene moraine generation at the Pamir Plateau might reflect phases of increasing moisture supply (cf. Abramowski et al. (2006); Fig. 4, no. 9-12), caused by phases of intensified ISM (for an overview phases of intensified ISM, see Bookhagen et al. (2005); Herzschuh (2006)). Ambiguously, they might also be linked to the temperature decrease during the post-Younger Dryas event at 
10.5 kyr (compare to Alay Range further north; Fig. 4, no. 7; Abramowski et al. (2006)). Evidence of younger glacial advances with potential links to the Westerliesdriven moisture increase during the Mid-Holocene (Herzschuh, 2006) are not resolved. Only the well-defined glacial advances in the eastern Pamir, at Muztagh Ata (Fig. 4, no. 13), record quasi-periodic climate oscillations throughout the Holocene (Seong et al., 2009a). Wang et al. (2011) distinguished two glacial stages at $1.5-0.4 \mathrm{kyr}$ and during the Little Ice Age, which they attribute to Northern Hemisphere climate oscillations. However, Herzschuh (2006) proposes that Westerly-dominated regions have received reduced moisture since the Late Holocene.

In contrast, Koppes et al. (2008) describe limited glacial advances from the Tien Shan (Fig. 4, no. 1-2) associated with Mid- and Late Holocene. No Holocene moraines are dated in the Terskey Ala-Too and At-Bashy Ranges by Narama et al. (2007, 2009); Fig. 4, no. 3) and Zech (2012); Fig. 4, no. 5). In regions south of Pamir, Owen et al. (2002a) and Seong et al. (2007) assume the Holocene, characterized by less prominent glaciations to respond to Northern Hemisphere cooling cycles. Owen et al. (2002b,a) and Seong et al. (2007) describe a post-Younger Dryasrelated glacial advance at $\sim 10.8 \mathrm{kyr}$ (Hunza valley, Fig. 4 , no. 17) and Mid- or Late Holocene, and/or the Little Ice Age advances (Chitral valley and central Karakoram, Fig. 4, no. 16 and 18).

The sensitivity of the Pamir region to climatic changes has important implications for the glacial dynamic and hence for the reconstruction of paleoclimatic conditions ((Zech et al., 2005a,b). Its position within the transition zone between the Westerlies and the ISM suggests that shifts of the two atmospheric circulation systems can result in considerable changes in moisture supply to the region. Therefore, linking the Quaternary glacial chronology of the Pamir (overview in Fig. 4) to Northern Hemisphere cooling cycles or monsoon-driven (moisture) cycles is challenging. Existing 10Be-based investigations of Zech et al. (2005a,b), Abramowski et al. (2006), and Röhringer et al. (2012) point toward glacial advances that are only partly contemporaneous with climatic cold phases in the Northern Hemisphere. Moraines associated with the characteristic, Westerlies-driven, last glacial maximum (LGM) during marine isotope stage (MIS) 2 are ubiquitously present, but they reflect significantly smaller extents compared to earlier Late Pleistocene advances. The maximum of Late Pleistocene glaciation in Pamir occurred most probably during MIS 4 or even before (cf. Zech et al. (2005a); Abramowski et al. (2006); Röhringer et al. (2012)). Furthermore, several exposure ages suggest glacial advances contemporaneous with the local LGM at MIS 3, typical for the ISM-driven Tibetan Plateau (Phillips et al., 2000; Kamp et al., 2004; Owen et al., 2008). This suggests that the glacial advances in Pamir are not only sensitive to the cold phases resulting from insolation minima but also to moisture advection from the prevailing atmospheric circulation (cf. Röhringer et al. (2012)). The records of mul- tiple Late Pleistocene glaciation cycles outline the influence of glacial imprints due to erosion and the corresponding sediment flux on the Quaternary landscape evolution. Hence, past changes in atmospheric circulation patterns potentially contributed to the evolution of the drainage network by driving river discharge and sediment budgets.

\section{Geomorphological characteristics}

The surface processes respond to the described tectonic and climatic conditions. Both, the evolving relief and corresponding drainage network, record variations of surface processes. They indicate spatial and temporal changes in the respective roles of controlling factors that basically comprise both, precipitation and base level (e.g. Leland et al., 1998; Hancock and Anderson, 2002; Bull, 2007). While relief characteristics and drainage network indicate mainly regional trends, in particular proxies of fluvial incision, highlighted areas are affected by local changes along the course of a river. It is then possible to evaluate the potential culprits such as precipitation, catchment geometry, rock types, and tectonic structures (cf. chapters 2 and 3). We characterize the interplay between relief and precipitation of the Westerlies and the ISM along four swath profiles across the Pamir Plateau toward its margin (Fig. 5). We further focus on the pattern of fluvial incision along the Panj to resolve spatial variations and to detect the areas of increased riverbed adjustment that illustrates deviations from a graded river. As proxies for the fluvial incision, we combine variations in valley shape ratios along with indication from valley swath profiles (Figs. 6, 7) and that of the longitudinal profile of Panj (Fig. 8).

\subsection{The relief}

We extracted four swath profiles from a DEM of $30 \mathrm{~m}$ resolution to quantify variations in the topographic relief across the Pamir (location cf. Fig. 1B). The swath profiles represent the range of altitudes within $20 \mathrm{~km}$ broad swath running perpendicular to the defined, central profile line. For each consecutive profile segment, they show the mean altitude (gray line) as well as its maximum and minimum (gray shaded area). We superimposed TRMM annual precipitation data extracted along the same profile (Fig. 5).

The four swath profiles illustrate the variations in relief between the Pamir Plateau and its margins. The Pamir Plateau displays low variations relative to the mean altitude of $\sim 4,500 \mathrm{~m}$ a.s.l. (cf. Fig. 5, swath profiles P1, P2, and P3). The minimum altitudes throughout the Pamir Plateau show a persistent level at $\sim 4,000 \mathrm{~m}$ a.s.l. and witnesses a very flat isobase. The large areas of low frequent changes in local base levels indicate wide, flat intra-plateau valleys. River incision is not reflected below that elevation (cf. Fig. 5, swath profile P4). The indicated limited ability of rivers to transport material toward the plateau margins and out of the Pamir Plateau coincides with the 

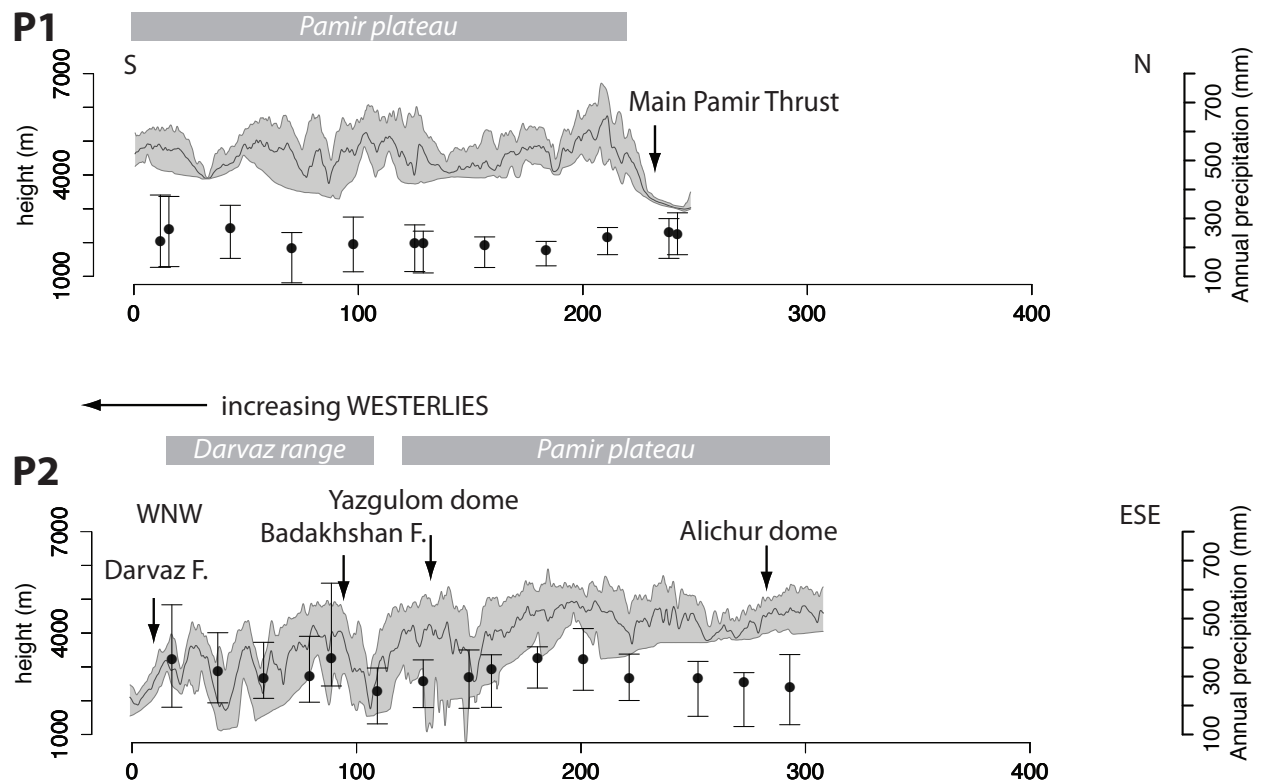

\section{P3 $\longleftarrow$ increasing WESTERLIES}
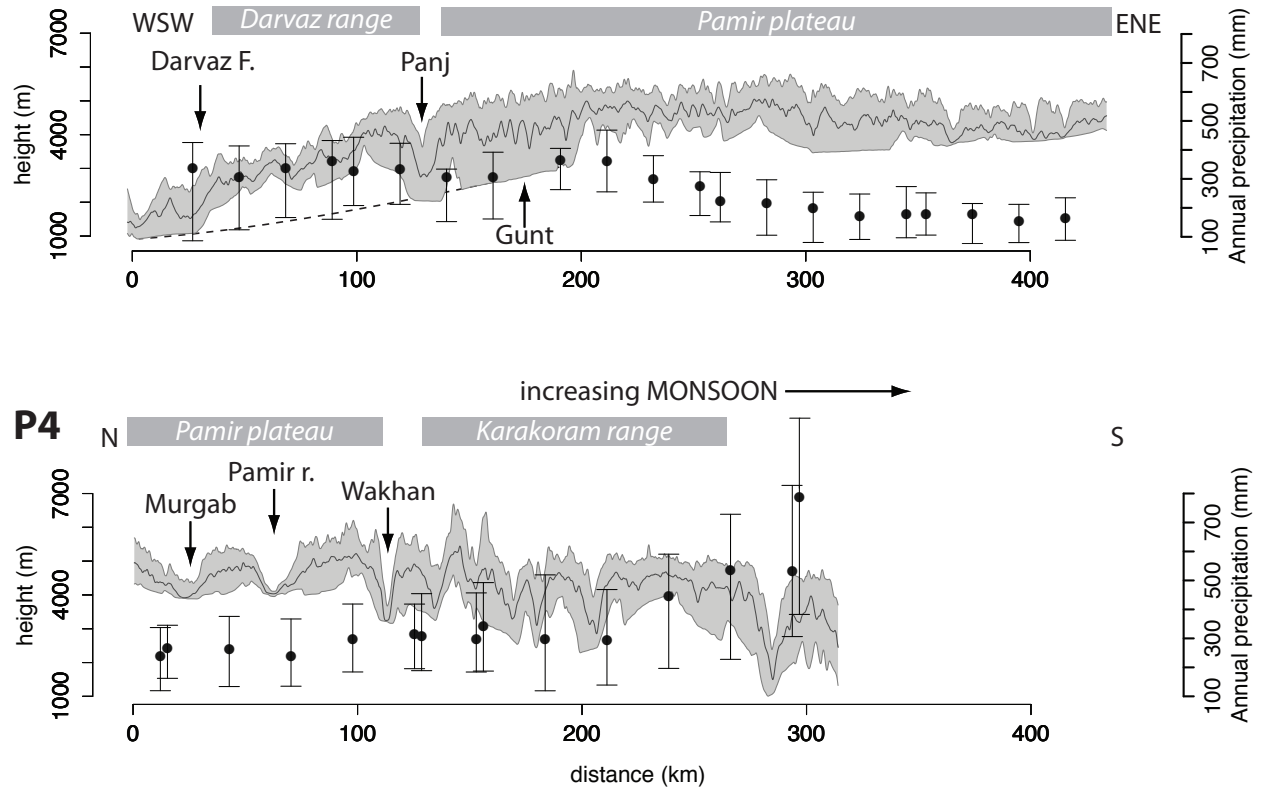

Figure 5: Swath profiles showing the mean altitude (solid line) and topographic variation (gray shaded area), extracted from a DEM $(30 \mathrm{~m} \times 30 \mathrm{~m})$ within a distance of $10 \mathrm{~km}$ from both sides of the central profile line (P1-4, locations see Fig.1B) and the annual precipitation based on TRMM data $(25 \mathrm{~m} \times 25 \mathrm{~km})$

low amount of precipitation penetrating into the Pamir Plateau (cf. Figs. 3, 5). The second and third profiles (P2 and P3 in Fig. 5) illustrate the decreasing mean altitudes at the western plateau margin. High variations, especially at minimum altitudes, coincide with the gradient of Westerlies-induced precipitation. Deeply incised valleys outline the boundaries between mountain ranges and reflect river down-cutting far below 4,000 $\mathrm{m}$ a.s.l., resulting in high variations of the local base level (cf. Fig. 7, photographs D, E, and F). The intensities of monsoonal precipitation attenuate before reaching the Pamir. The moisture gradient concurs with lower mean altitudes in the Karakoram Range along with high fluctuating altitudes (mean, minimum, and maximum) and deeply incised valleys (see Fig. 5, swath profile $\mathrm{P} 4$ ).

\subsection{The pattern of fluvial incision}

The pattern of fluvial incision along the Panj provides a valuable proxy to characterize areas of distinct surface response and more important, to outline the areas, that 
respond to variations in tectonic and/or climatic forcing. The Panj constitutes the major trunk river, which connects the westward-orientated river network at the western margin of the drainage basin. Hence, the Panj river incision traces the variations along the west-trending main drainage orientation within its strongly asymmetric drainage basin. Its northward-deflected river sections with deeply incised valleys record the effects of the consecutive following structural units and confluences with major tributaries.

We describe the relative intensities of fluvial incision along Panj by its valley geometry perpendicular to the river course (Figs. 6, 7). Changes in the valley morphometry indicate trends in valley slope response to fluvial incision and outline the areas of different control factors (Burbank and Anderson, 2001; Singh and Awasthi, 2010). To characterize the valley morphology, we extracted elevation data along more than 160 Panj valley cross-sections from a DEM of 30-m resolution and 6 swath profiles (cf. Fig. 7). Calculated valley shape ratios (VSR) represent the ratio of the valley width divided by the mean heights of left and right drainage divides (Burbank and Anderson, 2001). Low VSR values suggest prolonged base-level changes and pronounced fluvial incision, whereas high VSR values indicate that the landscape is less affected by recent increase in discharge and/or relative base-level lowering (Burbank and Anderson, 2001; Bull, 2007). The trends in VSR document subsequent river segments that are characterized by valley sections with high VSR followed by sections of strongly decreasing VSR and separated by an abrupt increase in VSR (Fuchs et al., 2012). The wide valleys sections correspond in general to east-west-trending valleys and confluences of major tributaries. However, the evidence of abrupt valley widening also coincides with tectonic structures such as the SPSZ or the Gunt Shear Zone (GSZ; cf. Fig. 6). The valley swath profiles and photographs $\mathrm{A}$ and $\mathrm{C}$ in Fig. 7 represent the wide valley at the Pamir Plateau and parallel to the SPSZ. The lowest VSR correspond to zones, where the Panj deflects northward and cuts the Shakhdara, Yazgulom, and Kurgovat Domes (Figs. 6, 7).

\subsection{Profile modelling}

The longitudinal profile of a river being in dynamic equilibrium has a smooth concave-up form. The bedrock erosion rate of a channel is a function of the stream power incision law (Hack, 1973). The slope $S$ of a channel is closely related to the drainage area (Hack, 1973) and the longitudinal profile length from river source (Hack, 1957):

$$
S=k_{1} A_{1}^{-\theta} \quad \text { or } \quad S=k_{2} D_{2}^{-\theta}
$$

where $k$ and $\theta$ are constants, and $D$ is the distance from the river source. The constants can be extracted from a logarithmic plot of slope versus distance or drainage area. The intercept and the slope of the linear regression determine $k$ and $\theta$. This scaling relationship is useful for reconstructing river profiles. Uplift and/or base-level changes modify the original concave shape of the profile. The resulting knickpoint separates the initial profile into two concave parts. In the case of an uplifted area, the higher portion of the river will be steeper while the lower portion will keep its original shape. If the river is affected by a base-level fall, the two segments will have a similar steepness. Using the slope-distance relationship (i.e., calculating constants for one of the two segments of the river profile), we can reconstruct the theoretical river profile (i.e., without knickpoint) prior to the uplift or base-level fall. In addition, the difference in elevation between the theoretical initial profile and the segment that experienced the uplift or the base-level fall provides an estimate on the amount of vertical displacement.

Here, we construct theoretical profiles that fit the concave portions of the Panj best. As they follow the powerlaw function relying slope to distance along the river course, these river segments are considered in equilibrium (i.e., uplift is balanced by incision in a configuration where transport capacity exceeds sediment flux). Practically, we perform a least-squares linear regression of the adequate portions in a log-log representation of slope versus distance to source. We then reconstruct the length profile using the extracted parameters (slope and intercept of the regression). The code has been developed in the $\mathrm{R}$ environment.

The extracted longitudinal profile presented in Fig. 8 highlights the composite, non-equilibrated character of the Panj. The slope-distance analysis indicates four major zones in which the Panj fits modelled equilibrated curves, i.e., in the Tajik Depression, in the Darvaz Range, between the rivers Shiva and Gunt, and from the northward deflection of Panj to Wakhan river (Fig. 8). The modelled Panj river length profile fitted from the river course in the Tajik Depression (lowermost profile on Fig. 8, further called "base-level Tajik Depression [BLTD]") clearly indicates that most of the Panj river is incompatible with a base level in the Tajik Depression. It implies that the upstream portions of the Panj did not reach an equilibrated stage since being connected to Tajik Depression drainage.

By fitting the equilibrated portion in the Darvaz Range, the modelled length profile is ca. $400 \mathrm{~m}$ above BLTD and the upstream portion fits the actual Panj profile in the Shiva region. It could indicate that, although convex on a large part and thus in strong disequilibrium, this portion represents an original drainage basin. The convex portion deviated about $300 \mathrm{~m}$ from the equilibrated profile and is roughly located in the area of the Yazgulom Dome.

The length profile extracted by fitting the Shiva-Gunt section is $1,500 \mathrm{~m}$ above BLTD and the modelled upstream reach fits the actual Panj riverbed in the Langar, where the Pamir and the Wakhan rivers merge. We propose that the section between the rivers Shiva and Wakhan represents a drainage unit, that is, in disequilibrium from the Gunt to the north deflection of Panj. The convex portion is about 300-400 $\mathrm{m}$ about the equilibrated profile and fits with the extent of the Shakhdara Dome. 


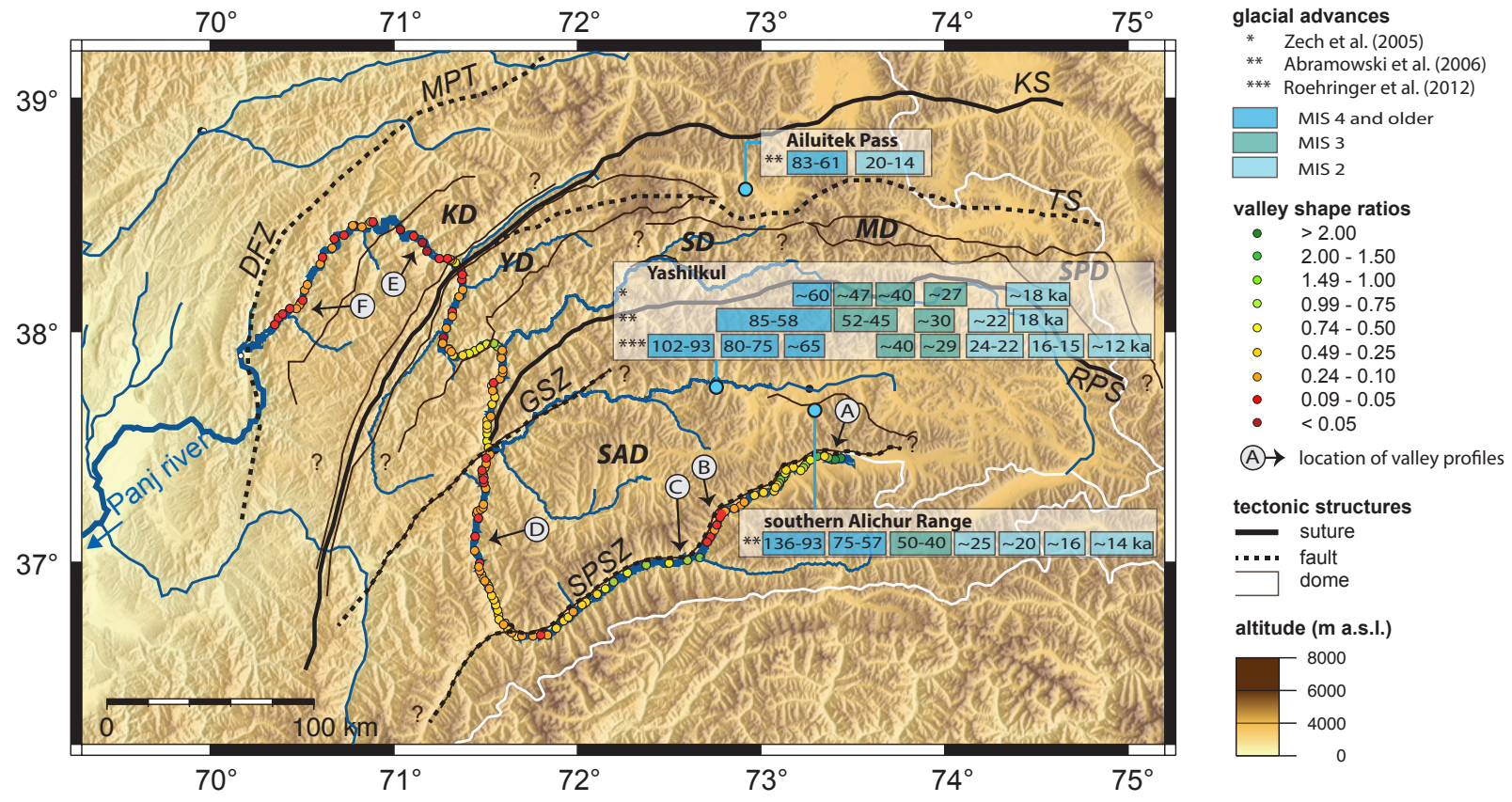

Figure 6: The characteristics of the Panj river network that drains the Pamir. Indications about the spatial and temporal variations of fluvial incision are illustrated by valley shape ratios along the Panj and timing of glacial advances at the Pamir plateau. The indicated locations of the valley profiles AF refer to the topographic profiles presented in Fig. 7 (abbreviations given in captions of Figs. 2, 8)

The last segment is represented by the Ishkashim-Langar section, which lies more than 2,200 $\mathrm{m}$ above BLTD. The Pamir river (the uppermost reach of the Panj profile) does not fit at all with the modelled profile and we therefore assume that this portion represents a very recent capture of the Pamir river by the Wakhan-Panj system. The convex portion is about $100 \mathrm{~m}$ above the equilibrated profile. Low riverbed gradients reflect that the Pamir river barely incises the orogen upstream of the convex portion. Fluvial erosion did not constraint hillslope processes in this part of Pamir (cf. Fig. 7, profile A).

The comparison to river orientation and tectonic structures links the major convex zones to the Shakhdara and Yazgulom Domes with very low channel slopes at the southern dome boundary and strong increases at the northern boundary. The downstream, stepwise increases in catchment are in general not reflected in the longitudinal profile or correlate in magnitude with changes in riverbed slopes. The profile modelling clearly indicates that the Panj is formed by the juxtaposition of river segments with different base levels that are incompatible with the fluvial response of a single drainage system to a base level located in the Tajik Depression. An absolute timing of the different captures is impossible to infer from the profiles but the intensities of the deflections to the modelled equilibrated profiles are compatible with more recent reorganizations upstream.

\section{Discussion}

The described geomorphometric characteristics of relief and drainage network outline complex temporal and spatial

variability in tectonic and climatic forcing on shaping the Pamir. The crustal shortening from the ongoing IndiaAsia collision forces the drainage network to align to the induced relief of east-west-trending mountain ranges. Structural discontinuities, inherited from the successive accretion of terranes, comprise potential sources of differential tectonic forcing on local base levels, which control river incision and the reorganization of the drainage network, e.g., river deflections and capture (Hancock and Anderson, 2002; Bull, 2007).

The deeply incised Panj river sections connect the main tributaries, the Gunt and Shakhdara, Bartang, Yazgulom, and Vanj rivers that drain the Pamir to the west and parallel to tectonic structures. The Panj deflects from this super-imposed orientation northwards, cutting the southern and central Pamir domes, their bounding faults (e.g., SPSZ and GSZ), and other major Cenozoic structures, and then doubles back to the southwest before entering the Tajik Depression (Fig. 6). The northward deflections are parallel to known structures such as the Central Badakhshan fault and major lineaments parallel to the DFZ and observable on satellite data. The local differences in incision outline the response of the Panj to consecutive local base levels by the consistent pattern of fluvial incision illustrated by valley morphologies along with VSR 

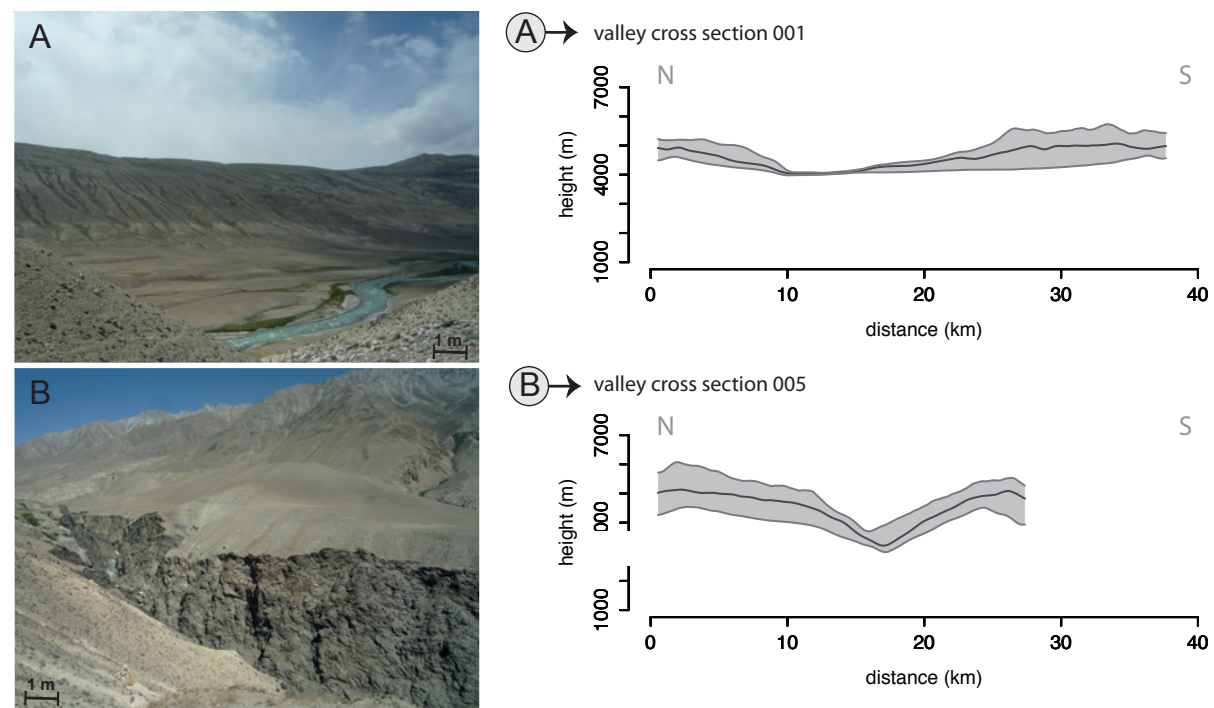

(B) $\rightarrow$ valley cross section 005
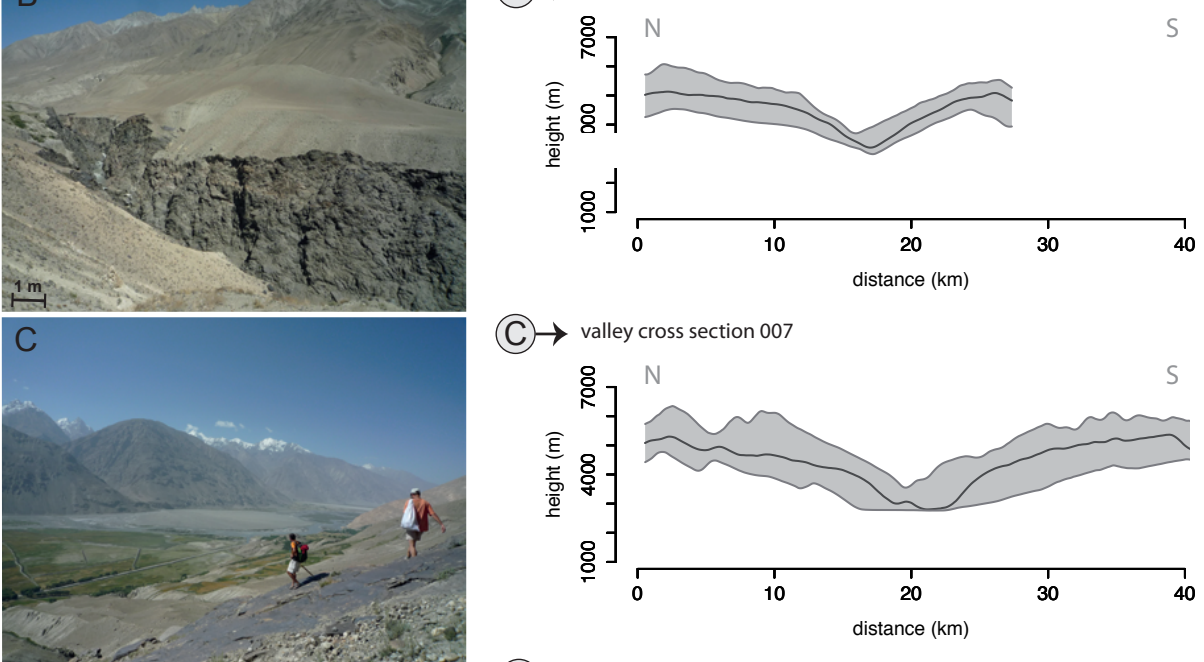

(C) $\rightarrow$ valley cross section 007
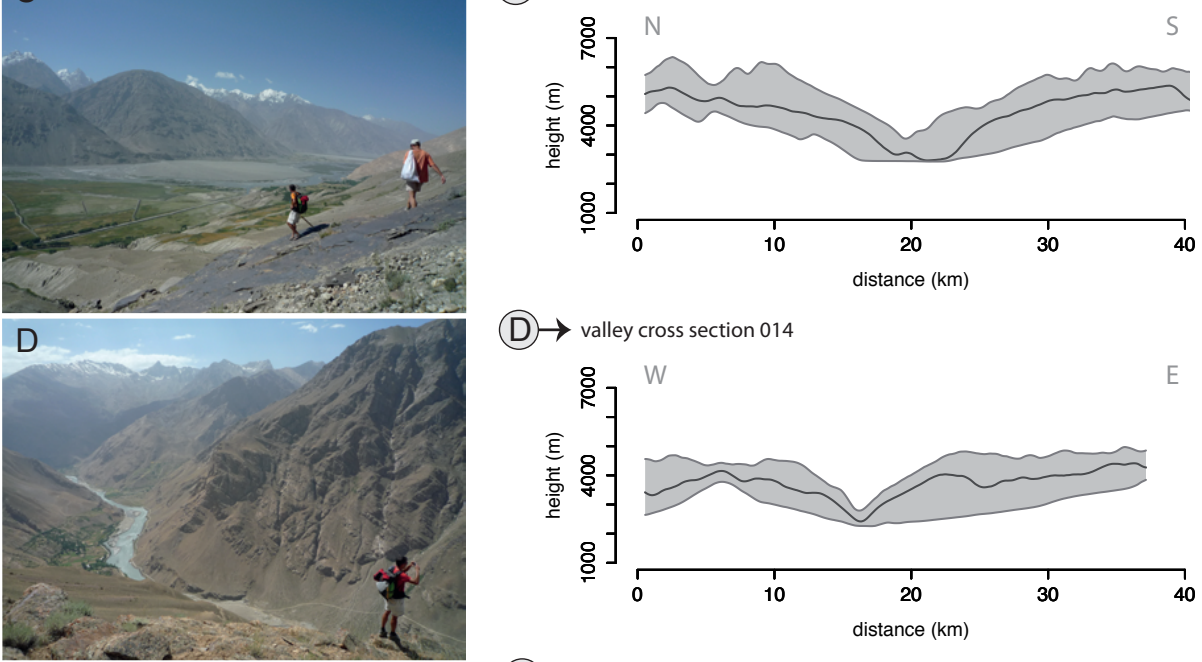

(D) $\rightarrow$ valley cross section 014
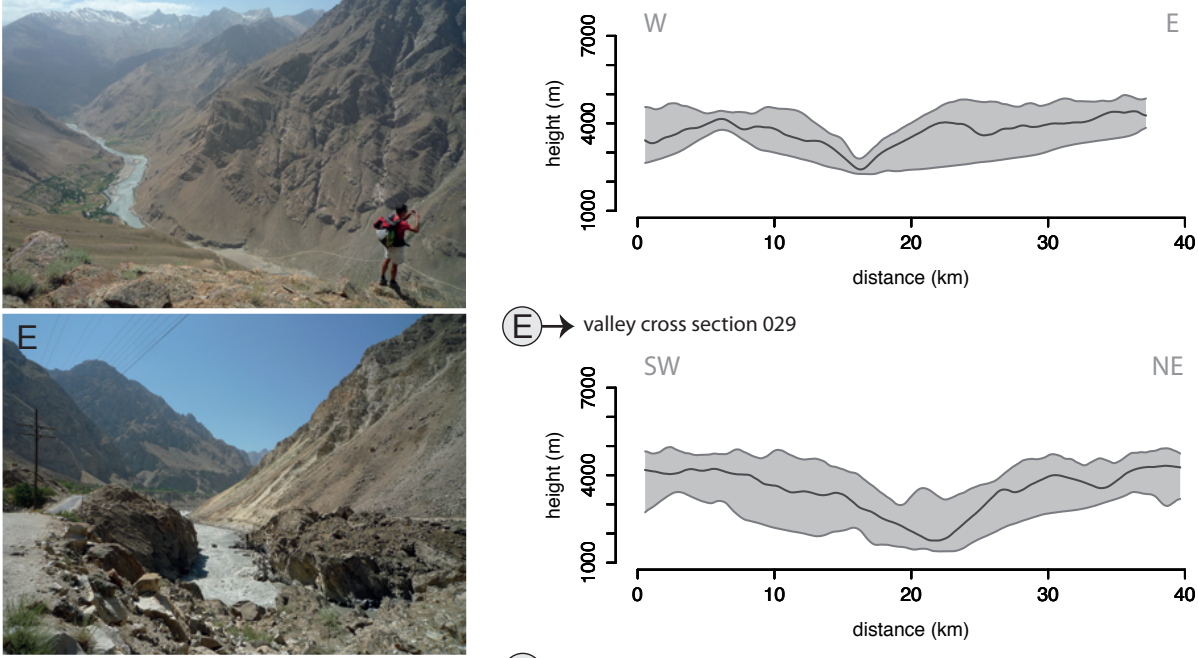

(E) $\rightarrow$ valley cross section 029
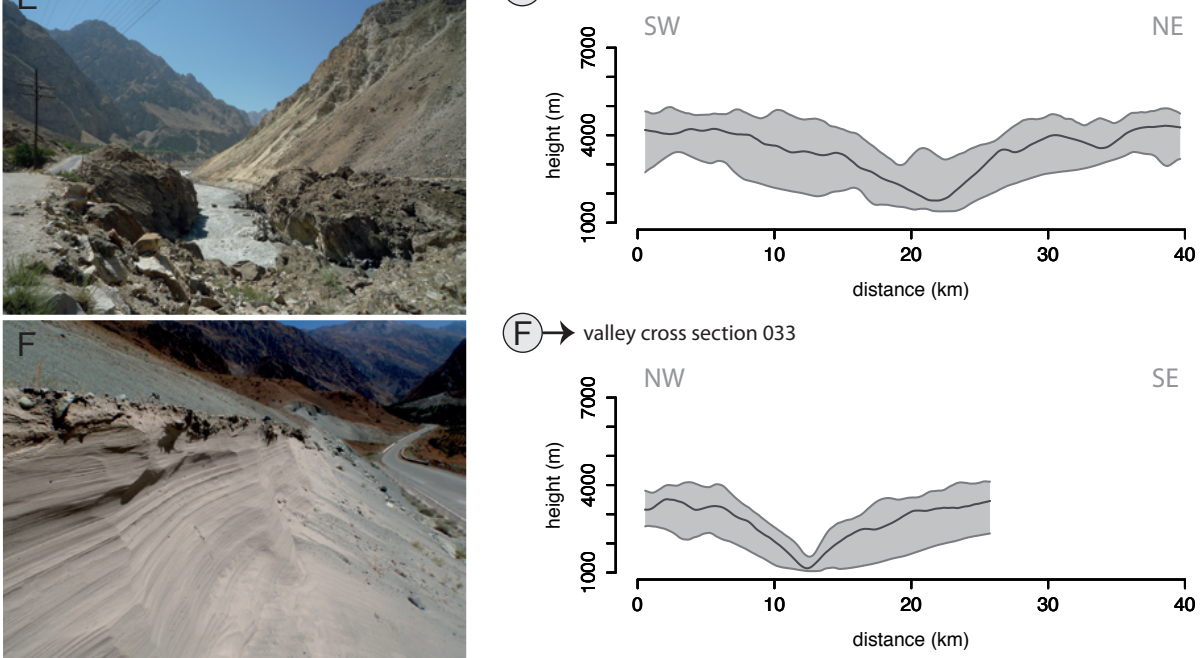

Figure 7: The valley profiles AF display the characteristic valley morphologies of the different river sections along Panj river. To avoid artefacts of profile extraction along a single line, we used swath profiles of $15 \mathrm{~km}$ width to describe the typical valley morphometry by the mean altitude (solid line) and deviation. 


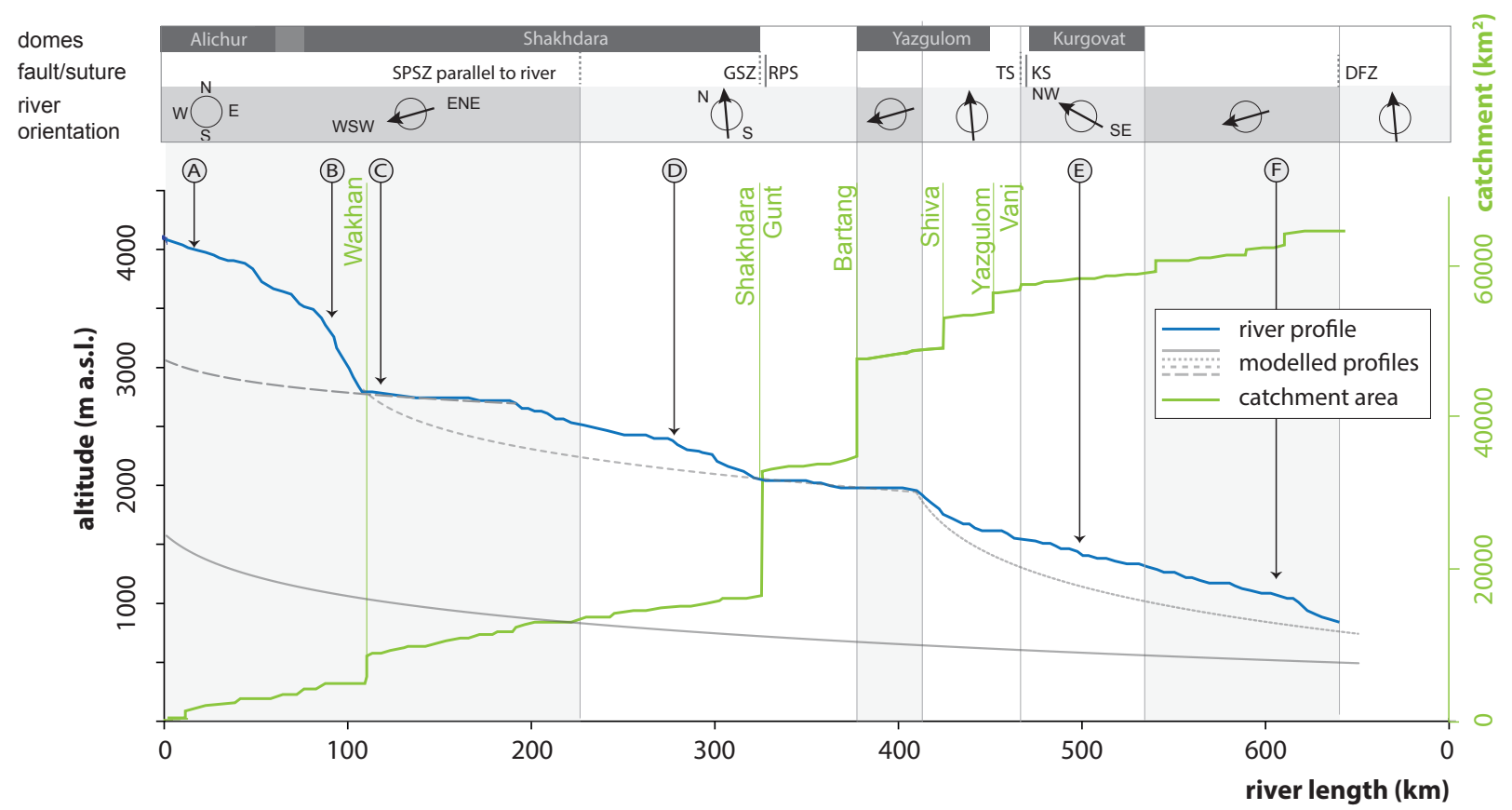

Figure 8: The longitudinal profile of Panj displays distinct, non-equilibrated river sections that are compared to the catchment, river orientation, and main tectonic structures (SPSZ Southern Pamir Shear Zone, GSZ Gunt Shear Zone, RPS Rushan-Psart-Suture, TS Tanymas Suture, KS Kunlun suture, DFZ Darvaz Fault Zone. The indicated locations of the valley profiles AF refer to the topographic profiles presented in Fig. 7.)

and profile modelling. The morphometric proxies distinguish basically two characteristic types of river sections, west-trending sections of low incision and north-trending sections of strongly increasing river incision.

The east-west-orientated southern part of Panj reflects two different units. The upper reach constitutes an extremely wide valley at $\sim 4,000 \mathrm{~m}$ a.s.l., corresponding to the intra-plateau valleys with characteristic low slopes and river incision not cutting into bedrock (Fig. 7, valley profile A). The downstream continuation resembles a less wide valley at $\sim 3,000 \mathrm{~m}$ a.s.l., but of roughly comparable low incision that exhibits a very straight river course along the SPSZ and parallel to the southern boundary of the Shakhdara Dome (Fig. 7, valley profile C). Similar valley morphologies are indicated for the southern boundary of the Yazgulom Dome. Minor, local valley widening is associated to confluences with other major tributaries such as the Gunt $(\sim 2,000 \mathrm{~m}$ a.s.l. $)$ and Vanj $(\sim 1,500 \mathrm{~m}$ a.s.l.) rivers. The valley cross-sections and locally preserved glacial sediments document the influence of Quaternary glaciations, but as outlined above, such glacial inheritance is difficult to associate to glacial cycles of the Pamir Plateau without numerical dating.

In contrast, northward-orientated river reaches represent the Panj crosscutting the Shakhdara and Yazgulom Domes and corresponding faults. The indicated strongly increasing fluvial incision (cf. Figs. 6, 8) suggests the river to respond to local base-level changes (cf. Fig. 7).
Indicated reaches coincide with the Panj connecting the main tributaries at the western margin of the asymmetric drainage basin (Figs. 6, 7, photographs and valley profiles $\mathrm{D}, \mathrm{E}$, and $\mathrm{F}$ ). The nearly perpendicular river deflections together with the apparent pattern of fluvial incision characterize the Panj as a composite river that responds to locally differential forcing (cf. Fig. 6). In particular, the modelled, equilibrated river segments fitted to the actual Panj profile indicate local base levels at $\sim 400, \sim 1,500$, and $\sim 2,200 \mathrm{~m}$ above the BLTD (Fig. 8). However, the three main reaches of the actual Panj river profile illustrate clear deviations from the modelled, theoretical profiles. The main convex zones indicate deviations above the theoretically equilibrated river to increase upstream from $\sim 300$ to nearly $1,000 \mathrm{~m}$ (Fig. 8 ). The convex zones agree with the indication of increased fluvial incision and with the Panj cutting the Kurgovat, Yazgulom, and Shakhdara Domes. We attribute the indicated trend of consecutively increasing deviations of the actual Panj profile from equilibrated models to subsequent river captures in response to locally differential base-level control.

We can rule out erodibility variations caused by different rock types. First, most the Pamir is constituted by stacked units of different composition but relatively uniform erosivity of bedrock. It is challenging to single out units, which might be more easily eroded along the main rivers. Secondly, the major anomalies in the organization of the river network (Fig. 6) and in the river profiles 
(Fig. 8) do not match with changes in rock types. Furthermore, the major confluences with Panj tributaries are not reflected by anomalies on the longitudinal profile. Erosivity and catchment geometry are not plausible for explaining the composite character of the Panj river.

The prevailing atmospheric circulations of the Westerlies and the ISM superimpose gradients of moisture supply on the Pamir relief (cf. Figs. 3, 5). Increased precipitation occurs during winter at the northwestern margin and therefore runoff is mainly controlled by temperature. To the south, the Karakoram and Hindu Kush mountains shield the Pamir from ISM-induced summer precipitation. Consequently, the central Pamir receives very little precipitation. The distribution of permanent ice and snow indicates moisture control by a rising ELA from $\sim 4,000 \mathrm{~m}$ a.s.l. at the Pamir margins to $\sim 4,800 \mathrm{~m}$ a.s.l. at the central plateau.

The gradients in precipitation correspond to specific relief morphologies (Fig. 5). The Pamir Plateau is characterized by low valley incision and smooth changes in local base level in contrast to its margins with deep incised valleys and high altitude variations (Fig. 5). We argue that the plateau has been shaped by glacial processes during wet periods and that, since the local LGM (during MIS 4 or earlier), increasing aridity limits surface processes. Corresponding fluvial capacities suggest only minor connectivity of sediment transport to the plateau margins. At the plateau margins, the currently highly incised valleys point toward fluvial processes that dominate the landscape evolution and over-print glacial landforms. However, control of the geometry of the river network (e.g., stepwise catchment increases due to confluences with tributaries) on the locally differential incision along the Panj is not indicated.

Past shifts in the atmospheric circulation triggered substantial climatic changes. Reconstructions suggest a maximum depression of paleo-ELA between $\sim 370$ and $\sim 260$ during the Pleistocene (cf. von Wissmann (1960), Abramowski et al. (2006)). Local evidences indicate that the most extensive glaciations to have reached the floors of plateau valleys during MIS4/5 or earlier (Röhringer et al., 2012). A deeper paleo-ELA with a maximum depression of $\sim 950 \mathrm{~m}$ have been suggested (Abramowski et al., 2006) but the timing and glacial extents are not resolved in the major Pamir rivers (cf. Fig. 4, no. 8-12; Fig. 6). As the ELA is mostly controlled by precipitation, the regionalization of local events is difficult. The disputed theory of a Late Pleistocene plateau glaciation in Central Asia assumes that a regionally uniform ELA depression of $\sim 1,000$ m (Grosswald et al., 1994; Kuhle, 1997, 2011) seems unlikely in Pamir. The two maxima in altitude frequencies at 3,600-4,100 $\mathrm{m}$ and 4,400-4,800 $\mathrm{m}$ a.s.l. are associated with the glacial erosion of two major Late Pleistocene glaciations at Muztagh Ata and Kongur Shan (Seong et al., 2009b). The lower maximum corresponds to the indicated local base level of the Pamir Plateau.

However, the few existing studies are concentrated on the Pamir Plateau and cannot fully resolve the glacial dy- namics during the Quaternary and the possible gradients toward the margins. Large moraine remnants in the westtrending valleys are not dated yet and we are unable to set these glacial markers into context to moraine stages at the Pamir Plateau, potential rooting zones or the recent glaciation. Assuming an ELA depression analog to the Pamir Plateau, where the most extensive glaciations during/pre-MIS 4 reached the inner-plateau valley floors $(\sim 4,000 \mathrm{~m}$ a.s.l.) and hence, glacial remnants in westtrending, lower altitude valleys $(<3,500 \mathrm{~m}$ a.s.l.) are older, may be erroneous. Due to the present, dry climate at the plateau, glaciers rise to higher altitudes compared to the margins (cf. Fig. 4A). But, the paleogradients of moisture supply and the links of glaciers that formerly occupied the west-trending valleys to potential rooting zones are largely unknown. One might argue that the west-trending valleys basically originate at the plateau suggesting links to plateau-internal rooting zones and corresponding glacial extents. However, potential paleogradients toward the margins need to be considered and require further investigations. Referring to the limited extent of glacial advances in neighbor regions (e.g., Hindu Kush and Tien Shan) and at the plateau, we suspect that glacial cycles did not cause or had only minor influences on perturbations of the Panj river dynamics at least since MIS 2 below $\sim 3,500 \mathrm{~m}$ a.s.l. Also, the regional consistent indication of an increasing aridity in Central Asia, since MIS 4 suggests glacial processes restricted to higher altitudes and hence, caused an overall decreasing role of glaciers on surface processes especially at the Pamir margins. The sediments from the Quaternary glaciations are still present at the plateau in the form of moraine remnants and huge valley fills. Both, the geometry of the Panj network and the pattern of fluvial incision, cannot be explained by the last glaciations, which were mostly confined to the Pamir Plateau.

Brookfield (2008) highlights the interaction of tectonic processes, climate changes, and local random effects, e.g., of landslides, on the development of major river systems draining Central Asia. The neotectonic deformation, especially documented by the records of recent seismology, is concentrated at the Pamir margins (cf. chapter 2.2. and Fig. 1B, Schurr et al. (2011); Sippl et al. (2012)). The corresponding earthquakes trigger landslides of various magnitudes and comprise an important forcing on mass movements in the region. The major earthquakes in Pamir and northeastern Afghanistan resulted in massive valley damming landslides, causing the related rivers to form among the biggest lakes of the region, lake Sarez, Yashilkul, and Shiva (Shroder et al., 2011). The Panj valley itself shows no signs of such extreme events causing long-term valley blocking. The local sediment supply is governed by gravitational mass movements from adjacent hillslopes, such as rockfall and debris, and by fan sedimentation. The outlined river sections of steep slopes, especially in the northward-deflected part, and the seasonal highly concentrated melt- water allow the Panj to incise and erode the supplied sediments rapidly. There- 
fore, we consider the effect of local mass movements on local base levels for river incision to represent only shortterm $\left(<10^{3}\right.$ years $)$ perturbations.

Brookfield (2008) presents an alternative hypothesis that interprets the northward Panj sections as the original, predominant drainage orientation corresponding to other major rivers draining Central Asia. Several arguments point against the hypothesis of an antecedent river, but speak for successive river captures across the main structural units of Pamir. First of all, the asymmetric drainage basin with the Panj close to the western divide and predominantly westward flowing rivers are not characteristic for an established long-term, north-draining river network. Secondly, the Panj experiences multiple river deflections from the westward but also from the northward drainage, corresponding to southern dome boundaries and tectonic structures parallel to the DFZ. That suggests the pattern of fluvial incision observed in the longitudinal profile and VSR not solely explained by an antecedent, north-trending river responding to differential tectonic uplift. Lowest incision in west-trending reaches corresponds to low forcing on river response parallel to the Pamir domes and mountain ranges. The northward-deflected river reaches, which indicate much higher incision, link the modelled base levels across the tectonic structures but do not connect to a straight northward river course. Thirdly, the deviations of the actual river profile from the modelled equilibrated profiles suggest upstream decreasing profile adjustment in response to local base levels. We interpret the increasing convexity by decreasing time intervals since capture, resulting from successive upstream river captures. Although possible, the control of differential rock uplift on local base levels is not resolved in our data.

It is too early to definitely statute whether these captures occur along active structures or are following inherited discontinuities. Nonetheless, several geomorphological evidences are supporting the fact that the rivers are controlled by active structures. The river profiles of most Panj tributaries are disequilibrated, showing convex profiles when they cross the domes. The main tributaries of the Panj (Vanj, Yazgulom, Bartang, Gunt) are located at dome boundaries and are extremely linear. The drainage system of the Panj is highly asymmetrical, with the northward flowing Panj itself being almost located at the western drainage. The tributaries of the Panj are parallel to the main trunk at the southern boundary of the Shakhdara Dome. The north-south linear structures guiding the Panj may be associated with active faults parallel to the DFZ and the Central Badakhshan fault, accommodating the northward motion of the Pamir indenter.

\section{Conclusion}

It makes no doubt that the shaping of Pamir is controlled by the complex interplay of tectonic and climatic forces, whereas the inhering fundamental question remains: what are their respective roles in the evolution of the Panj river network? Ongoing intra-continental collision of the Indian and Eurasian plate results in east-west-trending mountain ranges, bending along major slip fault zones. The river network illustrates the structural control by the main westward draining rivers in Pamir, which coincide with the Shakhdara and the Yazgulom Dome and related bounding faults. The northward-deflected sections of the Panj connect the main tributaries at the western margin of the drainage basin.

The interplay of the Westerlies and ISM superimposes gradients of moisture supply from the Pamir Plateau to its margins. Low amounts of precipitation limit recent ice and snow cover to high altitudes ([4,800 $\mathrm{m}$ a.s.l.), and the ability of rivers to incise and erode the sediment supplied to the wide plateau valleys. Low variations from the mean altitude of $\sim 4,500 \mathrm{~m}$ a.s.l. and consistent local base levels at $\sim 4,000 \mathrm{~m}$ a.s.l. on the Pamir Plateau reflect wide valleys and restricted fluvial incision. Glacial chronologies suggest an important influence of the glacial processes on the plateau relief. The maximum Quaternary glaciation during MIS 4 or earlier reached the innerplateau valley floors. Successively reduced glacial extents agree to chronologies from eastern Pamir, Tien Shan, and Hindu Kush that correspond to an increasing aridity in Central Asia. Hence, glacial morphodynamics may be limited to the Pamir Plateau since MIS 4. The post-glacial fluvial dynamics on the plateau did not suffice yet to transport sediments to the margins. Glaciations that reached lower altitudes are indicated by moraine remnants within the west-trending, wide valley sections of the Panj river network by moraine remnants. The timing and potential rooting zones of glacial advances at the plateau are not constrained.

Toward the plateau margins, the gradients of increasing precipitation superimpose the regional pattern of decreasing altitudes and higher relief variations that differentiate the glacial-controlled plateau from its fluvial-driven margins. We argue that the climatic gradients are not plausible contributors for the control of the orientation of the river course and of the pattern of reaches with increasing fluvial incision along the Panj. The local base-level changes that drive the river incision do not match with variations in bedrock erodibility and do not correspond in magnitude to the increases in catchment from tributary confluences.

We propose that the Panj is a composite river of reaches that respond to distinct local base levels. Profile modelling of theoretical, equilibrated profiles fitted three main river reaches with base levels at $\sim 400, \sim 1,500$, and $\sim 2,200$ $\mathrm{m}$ above the BLTD. The modelled base levels of theoretically equilibrated river sections correspond to the Darvaz Range, the section between the rivers Shiva and Bartang at the southern boundary and the river reach parallel to the SPSZ at the southern boundary of the Shakhdara Dome. The sections of the actual Panj river that are not locally equilibrated agree with zones of increased fluvial incision characterized by high VSR, where the Panj cuts 
the Pamir domes. While the river section related to the modelled base level at the Darvaz Range deviated $\sim 300 \mathrm{~m}$ above the equilibrated profile, the upstream reaches related to the Shiva-Bartang base level and to the one south of the Shakhdara Dome deviate up to $\sim 400 \mathrm{~m}$ a.s.l. and $\sim 1,000 \mathrm{~m}$ a.s.l.. We associate the increasingly convex zones and local base levels to successive river captures in response to active tectonics causing locally different baselevel control across the major tectonic structures in Pamir. It remains unclear whether the Cenozoic domes forming the bulk of the Pamir are still active or probably reactivated by recent deformation along DFZ parallel faults.

\section{Acknowledgments}

We thank the DFG for funding our research associated with the TIPAGE project (Gl361/4-1) and we also want to thank the Academy of Science of Tajikistan for supporting our fieldworks. We used GMT (Wessel, P. and W. H. F. Smith, New, improved version of the Generic Mapping Tools released, EOS Trans. AGU, 79, 579, 1998) QGIS (http://qgis.org/) and the R environment (http://www.rproject.org/) for most of the geomorphological processings and the resulting figures.

\section{References}

Abramowski, U., Bergau, A., Seebach, D., Zech, R., Glaser, B., Sosin, P., Kubik, P.W., Zech, W., 2006. Pleistocene glaciations of Central Asia: Results from ${ }^{10}$ Be surface exposure ages of erratic boulders from the Pamir (Tajikistan), and the Alay-Turkestan range (Kyrgyzstan). Quaternary Science Reviews .

Andermann, C., Bonnet, S., Gloaguen, R., 2011. Evaluation of precipitation data sets along the Himalayan front. Geochemistry Geophysics Geosystems .

Barry, R.G., 2008. Mountain Weather and Climate . Cambridge University Press.

Benn, D.I., Owen, L.A., 1998. The role of the Indian summer monsoon and the mid-latitude westerlies in Himalayan glaciation: Review and speculative discussion. Journal of the Geological Society

Bershaw, J., Garzione, C.N., Schoenbohm, L., Gehrels, G., Tao, L., 2012. Cenozoic evolution of the Pamir plateau based on stratigraphy, zircon provenance, and stable isotopes of foreland basin sediments at Oytag (Wuyitake) in the Tarim Basin (west China). Journal of Asian Earth Sciences .

Bookhagen, B., Burbank, D.W., 2010. Toward a complete Himalayan hydrological budget: Spatiotemporal distribution of snowmelt and rainfall and their impact on river discharge. Journal of Geophysical Research

Bookhagen, B., Thiede, R.C., Strecker, M.R., 2005. Late Quaternary intensified monsoon phases control landscape evolution in the northwest Himalaya. Geology .

Brookfield, M.E., 2008. Evolution of the great river systems of southern Asia during the Cenozoic India-Asia collision: Rivers draining north from the Pamir syntaxis. Geomorphology .

Brunel, M., Arnaud, N., Tapponnier, P., Pan, Y., Wang, Y., 1994. Kongur Shan normal fault: Type example of mountain building assisted by extension (Karakoram fault, eastern Pamir). Geology

Bull, B.W., 2007. Tectonic geomorphology of mountains - A new approach to paleoseismology. Blackwell Publishing.

Burbank, D.W., Anderson, R.S., 2001. Tectonic geomorphology. Wiley-Blackwell.
Burtman, V.S., Molnar, P., 1993. Geological and physical evidence for deep subduction of continental crust beneath the Pamir. GSA Special Papers .

Carrasco, J.F., Casassa, G., Quintana, J., 2005. Changes of the $0{ }^{\circ} \mathrm{C}$ isotherm and the equilibrium line altitude in central Chile during the last quarter of the 20th century / Changements de l'isotherme $0^{\circ} \mathrm{C}$ et de la ligne d'équilibre des neiges dans le Chili central durant le dernier quart du 20ème siècle. Hydrological Sciences Journal .

Chevalier, M.L., Tapponnier, P., Van Der Woerd, J., Ryerson, F.J., Finkel, R.C., Li, H., 2012. Spatially constant slip rate along the southern segment of the Karakorum fault since 200ka. Tectonophysics

Coutand, I., Strecker, M.R., Arrowsmith, J.R., Hilley, G., Thiede, R.C., Korjenkov, A., Omuraliev, M., 2002. Late Cenozoic tectonic development of the intramontane Alai Valley, (Pamir-Tien Shan region, central Asia): An example of intracontinental deformation due to the Indo-Eurasia collision. Tectonics

Cowgill, E., 2010. Cenozoic right-slip faulting along the eastern margin of the Pamir salient, northwestern China. Geological Society of America Bulletin .

Dee, D.P., Uppala, S.M., Simmons, A.J., Berrisford, P., Poli, P., Kobayashi, S., Andrae, U., Balmaseda, M.A., Balsamo, G., Bauer, P., Bechtold, P., Beljaars, A.C.M., van de Berg, L., Bidlot, J., Bormann, N., Delsol, C., Dragani, R., Fuentes, M., Geer, A.J., Haimberger, L., Healy, S.B., Hersbach, H., Hólm, E.V., Isaksen, L., Kållberg, P., Köhler, M., Matricardi, M., McNally, A.P., MongeSanz, B.M., Morcrette, J.J., Park, B.K., Peubey, C., de Rosnay, P., Tavolato, C., Thépaut, J.N., Vitart, F., 2011. The ERAInterim reanalysis: configuration and performance of the data assimilation system. Quarterly Journal of the Royal Meteorological Society .

Derbyshire, E., Yafeng, S., Li, J., Benxing, Z., Shijie, L., Wang, J., 1991. Quaternary glaciation of Tibet: The geological evidence. Quaternary Science Reviews .

Dodonov, A.E., 2002. The quaternary of middle Asia. Transactions of the Russian Academy of Science, Geological Institute .

Ducea, M.N., Lutkov, V., Minaev, V., Hacker, B.R., Ratschbacher, L., Luffi, P., Schwab, M., Gehrels, G.E., McWilliams, M., Vervoort, J., Metcalf, J., 2003. Building the Pamirs: The view from the underside. Geological Society of America .

Fan, G., Nil, J.F., Wallace, T.C., 1994. Active tectonics of the Pamir and Karakorum. Journal of Geophysical Research .

Frechen, M., Dodonov, A.E., 1998. Loess chronology of the Middle and Upper Pleistocene in Tadjikistan. Geologische Rundschau .

Fuchs, M.C., Gloaguen, R., Krbetschek, M.R., Szulc, A., 2012. OSL dating of fluvial terraces for incision rate estimation and indication of neotectonic activity in Pamir. Geophysical Research Abstracts

Gloaguen, R., Ratschbacher, L., 2011. Growth and collapse of the Tibetan Plateau: introduction. Geological Society, London, Special Publications .

Grosswald, M.G., Kuhle, M., Fastook, J.L., 1994. Würm Glaciation of Lake Issyk-Kul Area, Tian Shan Mts.: A Case Study in Glacial History of Central Asia. GeoJournal

Hack, J.T., 1957. Studies of longitudinal stream profiles in Virginia and Maryland. U.S. Geological Survey Professional Paper

Hack, J.T., 1973. Stream-profile analysis and stream-gradient index. Jour. Research US Geol. Survey .

Hancock, G.S., Anderson, R.S., 2002. Numerical modeling of fluvial strath-terrace formation in response to oscillating climate. Geological Society of America Bulletin

Herzschuh, U., 2006. Palaeo-moisture evolution in monsoonal Central Asia during the last 50,000 years. Quaternary Science Reviews

Hubberten, H.W., Andreev, A., Astakhov, V.I., Demidov, I., Dowdeswell, J.A., Henriksen, M., Hjort, C., Houmark-Nielsen, M., Jakobsson, M., Kuzmina, S., Larsen, E., Lunkka, J.P., Lyså, A., Mangerud, J., Möller, P., Saarnisto, M., Schirrmeister, L., Sher, A.V., Siegert, C., Siegert, M.J., Svendsen, J.I., 2004. The periglacial climate and environment in northern Eurasia during 
the Last Glaciation. Quaternary Science Reviews

Huffman, G.J., Adler, R.F., Arkin, P., Chang, A., Ferraro, R., Gruber, A., Janowiak, J., McNab, A., Rudolf, B., Schneider, U., 1997. The Global Precipitation Climatology Project (GPCP) Combined Precipitation Dataset. Bulletin of the American Meteorological Society .

Huffman, G.J., Bolvin, D.T., Nelkin, E.J., Wolff, D.B., Adler, R.F., Gu, G., Hong, Y., Bowman, K.P., Stocker, E.F., 2007. The TRMM Multisatellite Precipitation Analysis (TMPA): QuasiGlobal, Multiyear, Combined-Sensor Precipitation Estimates at Fine Scales. Journal of Hydrometeorology

Jarvis, A., Reuter, H., Nelson, A., 2008. Hole-filled seamless SRTM data V4.

Kamp, Jr., U., Haserodt, K., Shroder, Jr., J.F., 2004. Quaternary landscape evolution in the eastern Hindu Kush, Pakistan. Geomorphology

Koppes, M., Gillespie, A.R., Burke, R.M., Thompson, S.C., Stone, J., 2008. Late Quaternary glaciation in the Kyrgyz Tien Shan. Quaternary Science Reviews.

Koulakov, I., Sobolev, S.V., 2006. A tomographic image of Indian lithosphere break-off beneath the Pamir-Hindukush region. Geophysical Journal International .

Kuhle, M., 1997. New Findings concerning the Ice Age (Last Glacial Maximum) Glacier Cover of the East-Pamir, of the Nanga Parbat up to the Central Himalaya and of Tibet, as well as the Age of the Tibetan Inland Ice. GeoJournal .

Kuhle, M., 2011. The High Glacial (Last Ice Age and Last Glacial Maximum) Ice Cover of High and Central Asia, with a Critica Review of Some Recent OSL and TCN Dates. Elsevier Inc.

Le Pichon, X., Founder, M., Jolivet, L., 1992. Kinematics, topography, shortening, and extrusion in the india-eurasia collision. Tectonics

Leland, J., Reid, M.R., Burbank, D.W., Finkel, R.C., Caffee, M.W., 1998. Incision and differential bedrock uplift along the Indus River near Nanga Parbat, Pakistan Himalaya, from ${ }^{10} \mathrm{Be}$ and ${ }^{26} \mathrm{Al}$ exposure age dating of bedrock straths. Earth and Planetary Science Letters .

Mohadjer, S., Bendick, R., Ischuk, A., Kuzikov, S., Kostuk, A., Saydullaev, U., Lodi, S., Kakar, D.M., Wasy, A., Khan, M.A., Molnar, P., Bilham, R., Zubovich, A.V., 2010. Partitioning of India-Eurasia convergence in the Pamir-Hindu Kush from GPS measurements. Geophysical Research Letters

Narama, C., Kondo, R., Tsukamoto, S., Kajiura, T., Duishonakunov, M., Abdrakhmatov, K., 2009. Timing of glacier expansion during the Last Glacial in the inner Tien Shan, Kyrgyz Republic by OSL dating. Quaternary International

Narama, C., Kondo, R., Tsukamoto, S., Kajiura, T., Ormukov, C., Abdrakhmatov, K., 2007. OSL dating of glacial deposits during the Last Glacial in the Terskey-Alatoo Range, Kyrgyz Republic. Quaternary Geochronology

Nesje, A., 1992. Topographical effects on the equilibrium-line altitude on glaciers. GeoJournal

Owen, L.A., Caffee, M.W., Finkel, R.C., Seong, Y.B., 2008. Quaternary glaciation of the Himalayan-Tibetan orogen. Journal of Quaternary Science.

Owen, L.A., Chen, J., Hedrick, K.A., Caffee, M.W., Robinson, A.C., Schoenbohm, L.M., Yuan, Z., Li, W., Imrecke, D.B., Liu, J., 2012. Quaternary glaciation of the Tashkurgan Valley, Southeast Pamir. Quaternary Science Reviews .

Owen, L.A., Finkel, R.C., Caffee, M.W., Gualtieri, L., 2002a. Timing of multiple late Quaternary glaciations in the Hunza Valley, Karakoram Mountains, northern Pakistan: Defined by cosmogenic radionuclide dating of moraines. Geological Society of America Bulletin

Owen, L.A., Kamp, U., Spencer, J.Q., Haserodt, K., 2002b. Timing and style of Late Quaternary glaciation in the eastern Hindu Kush, Chitral, northern Pakistan: A review and revision of the glacial chronology based on new optically stimulated luminescence dating. Quaternary International

Phillips, W.M., Sloan, V.F., Shroder, J.F., Sharma, P., Clarke, M.L., Rendell, H.M., 2000. Asynchronous glaciation at Nanga Parbat, northwestern Himalaya Mountains, Pakistan. Geology

Pohl, E., Gloaguen, R., 2012. Suspended sediment flux characteristics in the central Pamirs. Geophysical Research Abstracts

Prigent, C., 2010. Precipitation retrieval from space: An overview. Comptes rendus - Geoscience.

Ratschbacher, L., Frisch, W., Liu, G., Cheng, C.C., 1994. Distributed deformation in southern and western Tibet during and after the India-Asia collision . Journal of Geophysical Research

Reigber, C., Michel, G.W., Galas, R., Angermann, D., Klotz, J., Chen, J.Y., Papschev, A., Arslanov, R., Tzurkov, V.E., Ishanov, M.C., 2001. New space geodetic constraints on the distribution of deformation in Central Asia. Earth and Planetary Science Letters

Richards, B.W., Owen, L.A., Rhodes, E.J., 2000a. Timing of Late Quaternary glaciations in the Himalayas of northern Pakistan. Journal of Quaternary Science

Richards, B.W.M., Benn, D.I., Owen, L.A., Rhodes, E.J., Spencer, J.Q., 2000b. Timing of late Quaternary glaciations south of Mount Everest in the Khumbu Himal, Nepal. Geological Society of America Bulletin

Robinson, A.C., Yin, A., Lovera, O.M., 2010. The role of footwall deformation and denudation in controlling cooling age patterns of detachment systems: An application to the Kongur Shan extensional system in the Eastern Pamir, China. Tectonophysics

Robinson, A.C., Yin, A., Manning, C.E., Harrison, T.M., Zhang, S.H., Wang, X.F., 2004. Tectonic evolution of the northeastern Pamir: Constraints from the northern portion of the Cenozoic Kongur Shan extensional system, western China. Geological Society of America Bulletin

Robinson, A.C., Yin, A., Manning, C.E., Harrison, T.M., Zhang, S.H., Wang, X.F., 2007. Cenozoic evolution of the eastern Pamir: Implications for strain-accommodation mechanisms at the western end of the Himalayan-Tibetan orogen. Geological Society of America Bulletin

Roe, G.H., 2005. Orographic precipitation. Annual Review of Earth and Planetary Sciences

Röhringer, I., Zech, R., Abramowski, U., Sosin, P., Aldahan, A., Kubik, P.W., Zöller, L., Zech, W., 2012. The late Pleistocene glaciation in the Bogchigir Valleys (Pamir, Tajikistan) based on ${ }^{10}$ Be surface exposure dating. Quaternary Research

Schmidt, J., Hacker, B.R., Ratschbacher, L., Konstanze, S.b., Stearns, M., Kylander-Clark, A., Cottle, J.M., Alexander, A., Webb, G., Gehrels, G., Minaev, V., 2011. Cenozoic deep crust in the Pamir. Earth and Planetary Science Letters

Schurr, B., Yuan, X., Schneider, F., Sippl, C., Mechie, J., Minaev, V., Abdybachaev, U., Oimahmadov, I., Gadoev, M., Negmatullaev, S., 2011. Seismicity and lithospheric structure in the PamirHindu Kush - Tien Shan region from TIPAGE seismological data. Geophysical Research Abstracts

Schwab, M., Ratschbacher, L., Siebel, W., McWilliams, M., Minaev, V., Lutkov, V., Chen, F., Stanek, K., Nelson, B., Frisch, W., Wooden, J.L., 2004. Assembly of the Pamirs: Age and origin of magmatic belts from the southern Tien Shan to the southern Pamirs and their relation to Tibet. Tectonics

Seong, Y.B., Owen, L.A., Bishop, M.P., Bush, A., Clendon, P., Copland, L., Finkel, R., Kamp, U., Shroder, Jr., J.F., 2007. Quaternary glacial history of the Central Karakoram. Quaternary Science Reviews

Seong, Y.B., Owen, L.A., Yi, C., Finkel, R.C., 2009a. Quaternary glaciation of Muztag Ata and Kongur Shan: Evidence for glacier response to rapid climate changes throughout the Late Glacial and Holocene in westernmost Tibet. Geological Society of America Bulletin

Seong, Y.B., Owen, L.A., Yi, C., Finkel, R.C., Schoenbohm, L. 2009b. Geomorphology of anomalously high glaciated mountains at the northwestern end of Tibet: Muztag Ata and Kongur Shan. Geomorphology .

Shroder, J.F., Weihs, B.J., Schettler, M.J., 2011. Mass movement in northeast Afghanistan. Physics and Chemistry of the Earth

Singh, T., Awasthi, A.K., 2010. Stream profiles as indicator of ac- 
tive tectonic deformation along the Intra-Foreland Thrust, Nahan Salient, NW India. Current Science .

Sippl, C., Schurr, B., Schneider, F., Yuan, X., Mechie, J., Haberland, C., Gadoev, M., Oimahmadov, I., Abdybachaev, U., Orunbaev, S., Minaev, V., Negmatullaev, S., Rui, H., Pingren, L., 2012. Seismicity of the Pamir and Hindu Kush: new constraints on regional tectonics. Geophysical Research Abstracts .

Skofronick-Jackson, G.M., Kim, M.J., Weinman, J.A., Chang, D.E., 2004. A physical model to determine snowfall over land by microwave radiometry. IEEE Transactions on Geoscience and Remote Sensing .

Sobel, E.R., Schoenbohm, L.M., Chen, J., Thiede, R., Stockli, D.F., Sudo, M., Strecker, M.R., 2011. Late Miocene-Pliocene deceleration of dextral slip between Pamir and Tarim: Implications for Pamir orogenesis. Earth and Planetary Science Letters

Strahler, A., Muchoney, D., Borak, J., Friedl, M., Gopal, S., Lambin, E., Moody, A., 1999. MODIS Land Cover Product Algorithm Theoretical Basis Document (ATBD) Version 5.0 .

Strecker, M.R., Frisch, W., Hamburger, M.W., Ratschbacher, L., Semiletkin, S., Zamoruyev, A., Sturchio, N., 1995. Quaternary deformation in the Eastern Pamirs, Tadzhikistan and Kyrgyzstan. Tectonics .

Stübner, K., Ratschbacher, L., Whipp, D.M., Jonckheere, R., Dunkl, I., 2012. Exhumation of the Shaxdara gneiss dome, Pamir Mountains: Tectonics versus erosion. Geophysical Research Abstracts

Thompson, L.G., Yao, T., Davis, M.E., Henderson, K.A., MosleyThompson, E., Lin, P.N., Beer, J., Synal, H.A., Cole-Dai, J. Bolzan, J.F., 1997. Tropical Climate Instability: The Last Glacial Cycle from a Qinghai-Tibetan Ice Core. Science .

Trifonov, V.G., 1978. Late Quaternary tectonic movements of western and central Asia. Geological Society of America Bulletin .

Velichko, A.A., Kononov, Y.M., Faustova, M.A., 1997. The last glaciation of earth: size and volume of ice-sheets. Quaternary International .

Vlasov, N.G., Dyakov, Y.A., Cherev, E.S., 1991. Geological map of the Tajik SSR and adjacent territories.

Waldhoer, M., Appel, E., Frisch, W., Patzelt, A., 2001. Palaeomagnetic investigation in the Pamirs and its tectonic implications. Journal of Asian Earth Sciences .

Wang, J., Zhou, S., Zhao, J., Zheng, J., Guo, X., 2011. Quaternary glacial geomorphology and glaciations of Kongur Mountain, eastern Pamir, China. Science China Earth Sciences .

von Wissmann, H., 1960. Die Heutige Vergletscherung und Schneegrenze in Hochasien, mit Hinweisen Auf Die Vergletscherung Der Letzten Eiszeit.

Zabirov, R.D., 1955. Oledenenie Pamira (Glaciation in the Pamir). GeografGIZ.

Zech, R., 2012. A late Pleistocene glacial chronology from the Kitschi-Kurumdu Valley, Tien Shan (Kyrgyzstan), based on ${ }^{10} \mathrm{Be}$ surface exposure dating. Quaternary Research .

Zech, R., Abramowski, U., Glaser, B., Sosin, P., Kubik, P.W., Zech, W., 2005a. Late Quaternary glacial and climate history of the Pamir Mountains derived from cosmogenic ${ }^{10}$ Be exposure ages. Quaternary Research .

Zech, R., Glaser, B., Sosin, P., Kubik, P.W., Zech, W., 2005b. Evidence for long-lasting landform surface instability on hummocky moraines in the Pamir Mountains (Tajikistan) from ${ }^{10}$ Be surface exposure dating. Earth and Planetary Science Letters . 